Original paper

\title{
Metamorphic reactions and textural changes in coronitic metagabbros from the Teplá Crystalline and Mariánské Lázně complexes, Bohemian Massif
}

\author{
Petra JAŠAROVÁ*, Martin RACEK, Petr JEŘÁBEK, František V. HOLUB ${ }^{\dagger}$ \\ Institute of Petrology and Structural Geology, Charles University, Albertov 6, 12843 Prague 2, Czech Republic; \\ petra.jasarova@natur.cuni.cz \\ * Corresponding author \\ ${ }^{+}$Deceased
}

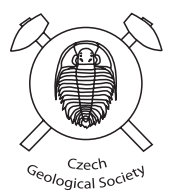

Coronitic metagabbros occur as small isolated bodies along the contact between the Mariánské Lázně and the Teplá Crystalline complexes in the northwestern part of the Teplá-Barrandian Unit in the Bohemian Massif. Metagabbros show variable metamorphic and textural characteristics with respect to their magmatic mineral assemblage and degree of metamorphism. The aim of this study has been to characterize the mineralogical, chemical, and microstructural changes related to metamorphism in selected samples. Magmatic mineral assemblages in the metagabbros represented by plagioclase, orthopyroxene, clinopyroxene, amphibole, biotite, ilmenite and occasionally involving olivine, spinel or quartz are generally well preserved. Metamorphism is mainly reflected by the formation of single or multiple coronas at the contact of plagioclase with the other primary minerals. The coronas typically consist of amphibole, garnet and orthopyroxene. The progressive breakdown of magmatic plagioclase is reflected by the formation of a mixture of $\mathrm{An}_{40}$ and $\mathrm{An}_{90}$ plagioclase associated with spinel, corundum and locally also kyanite. The calculated $\mathrm{P}-\mathrm{T}$ conditions show an increase in metamorphic grade towards the structural footwall, i.e. from the east-southeast $\left(\sim 60 \pm \pm 50^{\circ} \mathrm{C} ; 10 \pm 1.5 \mathrm{kbar}\right)$ to the west-northwest $\left(\sim 700 \pm 50^{\circ} \mathrm{C} ; 13.5 \pm 1.5 \mathrm{kbar}\right)$, which corresponds to the previously reported Variscan metamorphic field gradient in this area. Since there is no gap in P-T conditions between metagabbros included in MLC and TCC and showing similar age and geochemical signature, it is concluded that both complexes were brought together before the gabbro intrusion at $\sim 500 \mathrm{Ma}$. In addition, the maximum pressure of $\sim 14 \mathrm{kbar}$ estimated for the metamorphism of the gabbro occurring in the eclogite-bearing Mariánské Lázně Complex suggests that the eclogite-facies metamorphism might have been pre-Variscan. The chemistry of the studied metagabbros corresponds to subalkaline basalts with traceelement signatures characteristic of E-MORB, which is consistent with an interpretation that the intrusion of these rocks was related to an intracontinental rifting of the Teplá-Barrandian Unit during Late Cambrian and was not connected to any subduction processes.

Keywords: corona, gabbro, Variscan metamorphism, Mariánské Lázně Complex, Teplá Crystalline Complex, Cambro-Ordovician extension

Received: 18 December, 2015; accepted: 26 August, 2016; handling editor: P. Hasalová

\section{Introduction}

The Bohemian Massif represents the easternmost segment of the European Variscides (Fig. 1a), which was consolidated during Late Devonian-Carboniferous subduction-collision process following the closure of the Saxothuringian/ Rheic Ocean (e.g. Matte et al. 1990; Franke 2000; Schulmann et al. 2009). The main evolutionary stages of the Bohemian Massif summarized by Schulmann et al. (2009, 2014) include 1) subduction of the Saxothuringian oceanic plate underneath the Teplá-Barrandian Unit at 430-350 $\mathrm{Ma}, 2)$ crustal thickening/relamination of the orogenic root domain at 350-340 Ma, and 3) relatively fast exhumation of the orogen core at 340-330 Ma.

The Teplá-Barrandian Unit (Fig. 1a) represents the uppermost part of the orogenic structure and, at the same time, it also provides the complete crustal section with little metamorphosed Precambrian and Lower Paleozoic rocks in the east and lower crustal rocks in the west (Peřestý 2012). The westernmost, structurally lowermost and the highest grade part of the Teplá-Barrandian Unit is represented by mainly mafic rocks of the Mariánské Lázně Complex (MLC) and the overlying Proterozoic metasediments of the Teplá Crystalline Complex (TCC). The MLC (Fig. 1b) has been interpreted as a relic of oceanic crust derived from the Saxothuringian/Rheic Ocean that was subducted to eclogite-facies conditions and exhumed during Devonian (Bowes and Aftalion 1991; Jelínek et al. 1997; Zulauf 1997; Dallmeyer and Urban 1998; Faryad 2012). In contrast, the continental crust of the TCC (Fig. 1b) records Cambro-Ordovician rift-related extension and an early Variscan orogenic 
(a)

SAXOTHURINGIAN / W. SUDETES / LUGIAN
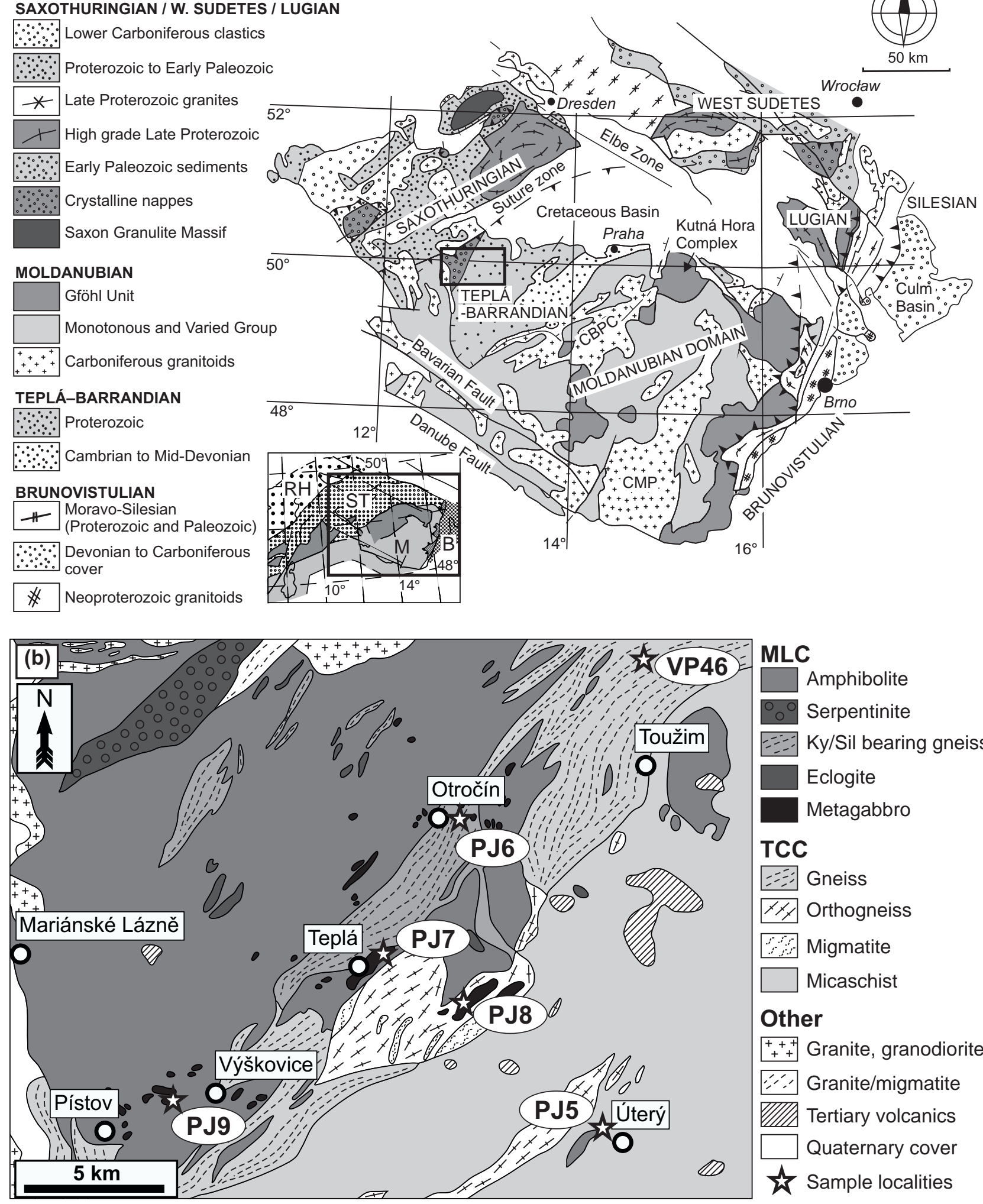

MLC

$\square$ Amphibolite

0 Serpentinite

$=:=-\mathrm{Ky} / \mathrm{S}$ il bearing gneiss

Eclogite

Metagabbro

TCC

泫 G neiss

Xy. Orthogneiss

G Migmatite

$\square$ Micaschist

\section{Other}

$\left[\begin{array}{c}+++ \\ ++\end{array}\right]$ Granite, granodiorite

$\because \because-1$ G ranite/migmatite

UII Th Tertiary volcanics

Quaternary cover

交 Sample localities

Fig. 1a - Simplified map of the Bohemian Massif (modified from Franke 2000). CBPC - Central Bohemian Plutonic Complex, CMP - Central Moldanubian Pluton. Bottom left corner - location of Bohemian Massif in the European Variscides (after Edel et al. 2003) RH - Rhenohercynian Zone, ST - Saxothuringian Zone, M - Moldanubian Zone, B - Brunia. b - Geological map of the contact between the Teplá Crystalline and Mariánské Lázně complexes. Simplified from the Geological map of the Czech Republic 1:500 000 (Cháb et al. 2007). 
thickening followed by exhumation during Devonian (Peřestý 2012). It is interesting to note that the Cambro-Ordovician rifting was associated with numerous intrusions of gabbroids identified in the TCC but also in the MLC, thus questioning their separate Variscan history (Štědrá et al. 2002; Timmermann et. al. 2004). Moreover it is not clear whether the two complexes shared the same Devonian metamorphic evolution, possibly manifested by the continuous increase in metamorphic grade towards the structural footwall, or whether they were mutually independent with a major metamorphic gap.

In this respect, the metamorphic record in the gabbro lenses, together with their spatial arrangement across the boundary between TCC and MLC bids for a systematic study. This work is focused on coronitic metagabbros, which occur as small isolated bodies in both the mafic rocks of MLC and the felsic rocks of TCC near the contact of the two complexes (Fig. 1b). These mafic magmatic intrusives of Cambro-Ordovician age were metamorphosed during Variscan while escaping the deformation overprint localized into the surrounding country rocks. Advantageously and in contrast to their host rocks, the mechanically resistant gabbro lenses were not affected by the exhumation-related deformation overprint, preserving well the peak metamorphic assemblages. The static metamorphism in the metagabbros thus provides an excellent opportunity to describe and characterize the relationships between the primary igneous minerals and their metamorphic coronitic overprint. In addition, the sequence of metamorphic phases in coronas together with their chemistry is used to estimate $\mathrm{P}-\mathrm{T}$ conditions of their formation by thermobarometric techniques.

\section{Geological setting}

\subsection{Mariánské Lázně Complex (MLC)}

The MLC is dominantly composed of amphibolites, which can be divided into several NE-SW trending belts (Kastl and Tonika 1984; Beard et al. 1995) (Fig. 1b). The central part of the MLC is occupied by the high-grade garnet- and rutile-bearing amphibolite hosting boudins of eclogite and HP granulite (Jelínek et al. 1997; Štědrá 2001; Timmermann et al. 2004; Faryad 2012; Hrouda et al. 2014). The high-grade belt is enveloped by garnetand titanite-bearing amphibolite and serpentinite body in the northwest that is ascribed to a separate unit (Kachlík 1993).

The MLC mafic rocks are subalkaline and follow the tholeiitic trend (Beard et al. 1995; Timmermann et al. 2004). Major- and trace-element compositions of eclogites fall within the N-MORB and E-MORB fields (Timmermann et al. 2004).
Peak metamorphic conditions of 16-23 kbar and $640-715{ }^{\circ} \mathrm{C}$ were estimated for the MLC eclogites (Jelínek et al. 1997; Štědrá 2001; Faryad 2012). Faryad (2012) distinguished two separate HP events recorded in the eclogites, the older one at $725^{\circ} \mathrm{C}$ and $17 \mathrm{kbar}$ and the younger one at $640^{\circ} \mathrm{C}$ and $27-28 \mathrm{kbar}$. According to O'Brien et al. (1997) the eclogites were overprinted by short-lived granulite-facies metamorphism followed by amphibolite-facies overprint.

Based on the $\mathrm{U}-\mathrm{Pb}$ zircon dating, the protolith ages of most of the MLC high-pressure rocks were Cadomian ( 560-535 Ma: Timmermann et al. 2004). The Variscan metamorphic ages in MLC were constrained to $380-365 \mathrm{Ma}$ by the $\mathrm{U}-\mathrm{Pb}$ dating of zircon and monazite (Timmermann et al. 2004). Similar cooling ages of 397-370 Ma were obtained by the K-Ar and ${ }^{40} \mathrm{Ar} /{ }^{39} \mathrm{Ar}$ dating of hornblende and interpreted to reflect the quick exhumation of MLC (Kreuzer et al. 1989; Zulauf 1997; Dallmeyer and Urban 1998; Bowes et al. 2002).

\subsection{Teplá Crystalline Complex (TCC)}

The TCC is dominated by the Proterozoic metasediments with several intrusions of Cambro-Ordovician granitoid plutons (Fig. 1b) transformed into orthogneisses during the Variscan Orogeny (Dörr et al. 1998). The metasediments revealed a Variscan metamorphic field gradient with northeast-southwest trending isograds (Cháb and Žáček 1994; Žáček 1994; Cháb et al. 1997; Zulauf 2001). The metamorphic conditions in the studied area increase towards the NW starting from the staurolite isograd with estimated P-T conditions of $5.0-7.7 \mathrm{kbar}$ and $530-620^{\circ} \mathrm{C}$ to the kyanite isograd with $5.0-8.7 \mathrm{kbar}$ and $550-645^{\circ} \mathrm{C}$ (Cháb and Žáček 1994; Žáček 1994). The timing of the Variscan metamorphism and exhumation in the TCC is constrained by $\mathrm{U}-\mathrm{Pb}$ monazite and $\mathrm{Ar}-\mathrm{Ar}$ muscovite ages ranging between 385 and $370 \mathrm{Ma}$ (Dallmeyer and Urban 1998; Timmermann et al. 2006).

Metagabbro bodies along the contact of the MLC and TCC (Fig. 1b) show well preserved magmatic textures with metamorphic corona overprint (e.g. Štědrá et al. 2002). On the basis of their compositions the metagabbros have been divided into several groups: Ti-rich, Mg-rich, alkali-rich, Rb-rich and transitional composition groups (Štědrá et al. 2002). Major- and trace-element chemistry of the metagabbros is tholeiitic (e.g. Beard et al. 1995; Štědrá et al. 2002; Timmermann et al. 2004). The geochemical character shows affinities to oceanic rocks (Beard et al. 1995) and more recent studies (Štědrá et al. 2002; Timmermann et al. 2004) show that the composition of metagabbros corresponds to E-MORB and T-MORB. Their metamorphic conditions were estimated to $8-11$ 
kbar and $600-730^{\circ} \mathrm{C}$ by Štědrá (2001), while slightly higher pressure and lower temperature of 12-13 kbar and $585-614{ }^{\circ} \mathrm{C}$ were calculated by Faryad (2012). The intrusive ages of metagabbros of 496-503 Ma were obtained by $\mathrm{U}-\mathrm{Pb}$ zircon dating (Bowes and Aftalion 1991; Timmermann et al. 2004).

\section{Analytical techniques}

\subsection{Mineral chemistry}

Composition of the minerals was determined in the laboratory of electron microscopy at the Institute of Petrology and Structural Geology (Charles University in Prague) using a scanning electron microscope Tescan VEGA equipped with an energy-dispersive spectrometer X-Max 50 (Oxford Instruments). Data were acquired and processed using the software INCA. Quantitative analyses were acquired with an acceleration voltage of $15 \mathrm{kV}$ and a probe current of $1.5 \mathrm{nA}$, compositional maps showing the distribution of specific elements were acquired at $15 \mathrm{kV}$ and $7 \mathrm{nA}$. Chemical composition of amphiboles was recalculated and classified following Leake et al. (1997), the $\mathrm{X}_{\mathrm{Mg}}$ was calculated as $\mathrm{Mg} /\left(\mathrm{Fe}^{2+}+\mathrm{Fe}^{3+}+\mathrm{Mg}\right)$. Mineral abbreviations used are according to Kretz (1983), Amp is used for amphibole.

\subsection{Geothermobarometry}

The $\mathrm{P}-\mathrm{T}$ estimates were obtained by applying the multiequilibrium thermobarometry (average pressure-temperature calculations, Powell and Holland 1994) in the software THERMOCALC v. 3.33 (Powell and Holland 1985,1988 , recent upgrade) using the internally consistent thermodynamic data set (Holland and Powell 1998: November 2003 upgrade). In addition, the P-T conditions were estimated using the "conventional" methods, i.e. the garnet-hornblende geothermometer of Ravna (2000) and the garnet-hornblende-plagioclase geobarometer of Kohn and Spear (1990).

Tab. 1 Sample list with geographic coordinates, localities and their characteristics

\begin{tabular}{lccll}
\hline locality & $\mathrm{N}$ & $\mathrm{E}$ & & surrounding rocks \\
\hline TCC & & & & \\
PJ 5 & 49.94146292 & 13.01445046 & NW of Úterý & micaschist (Ky zone) \\
TCC-MLC & & & & \\
PJ 8 & 49.96539376 & 12.90800532 & SE of Teplá & orthogneiss \\
PJ 7 & 49.97590793 & 12.86426051 & E of Teplá & amphibolite, Ky/Sil-bearing gneiss \\
VP 46 & 50.09017808 & 12.98426924 & near Chylice & gneiss \\
MLC & & & & \\
PJ 6 & 50.02928825 & 12.91391029 & near Otročín & garnet amphibolite with titanite \\
PJ 9 & 49.93372710 & 12.78617830 & W of Výškovice & garnet amphibolite with titanite \\
\hline
\end{tabular}

\subsection{Whole-rock geochemistry}

The chemical analyses of major and trace elements in the selected samples were carried out in order to characterize their magmatic origin. The samples were crushed with a jaw crusher and pulverized in an agate mill in the Laboratories of the Czech Geological Survey (Prague, Czech Republic). Pulverized and homogenized samples were analyzed in the Bureau Veritas Mineral Laboratories (Vancouver, Canada). The total whole rock characterization (code LF202, see http://acmelab.com/ pdfs/FeeSchedule-2016.pdf) was done using the lithium borate fusion ICP-ES (major and minor elements, code LF302) the lithium borate fusion ICP-MS (trace elements, code LF100), and Aqua Regia ICP-ES/MS (trace elements, code AQ200) methods. The geochemical data were plotted and interpreted using the Geochemical Data Toolkit (Janoušek et al. 2006).

\section{Petrography and mineral chemistry}

The studied samples were collected from six localities near the contact between the MLC and TCC (Fig. 1b, Tab. 1). They were divided into three groups with respect to their location: 1) metagabbros from the TCC; 2) metagabbros from the contact between the MLC and TCC; and 3) metagabbros from the MLC.

\subsection{Metagabbros from the TCC}

The sample PJ5 shows high degree of metamorphic recrystallization although the primary magmatic texture is still well preserved (Fig. 2). The observed mineral phases can be assigned either to the primary (presumably magmatic) assemblage $M_{1}$ or to the secondary metamorphic assemblage $\mathrm{M}_{2}$, the latter resulting from recrystallization of the primary minerals and development of coronas at their contacts. The $\mathrm{M}_{1}$ assemblage is generally coarse-grained and consists of plagioclase, amphibole, clinopyroxene, biotite, and ilmenite. Plagioclase grains up to $2 \mathrm{~mm}$ preserve euhedral shape and their composition ranges from andesine to labradorite $\left(\mathrm{An}_{49-54}\right.$; Fig. 3a) with increasing $\mathrm{Na}$ and decreasing $\mathrm{Ca}$ contents $\left(\mathrm{Ab}=46 \rightarrow 54 \%, \mathrm{An}_{53 \rightarrow 46}\right.$, Or $=0-1 \%)$ at their rims. Amphibole (pargasite-edenite, $\mathrm{X}_{\mathrm{Mg}}=0.51-0.58, \mathrm{Si}=6.18$ 6.63 apfu; Fig. 3e; Tab. 2) together with clinopyroxene (augite, $\mathrm{X}_{\mathrm{Mg}}=0.75-0.76$ and $\mathrm{Jd}=2.5-4$ mol. \%; Fig. $3 \mathrm{c}$; 

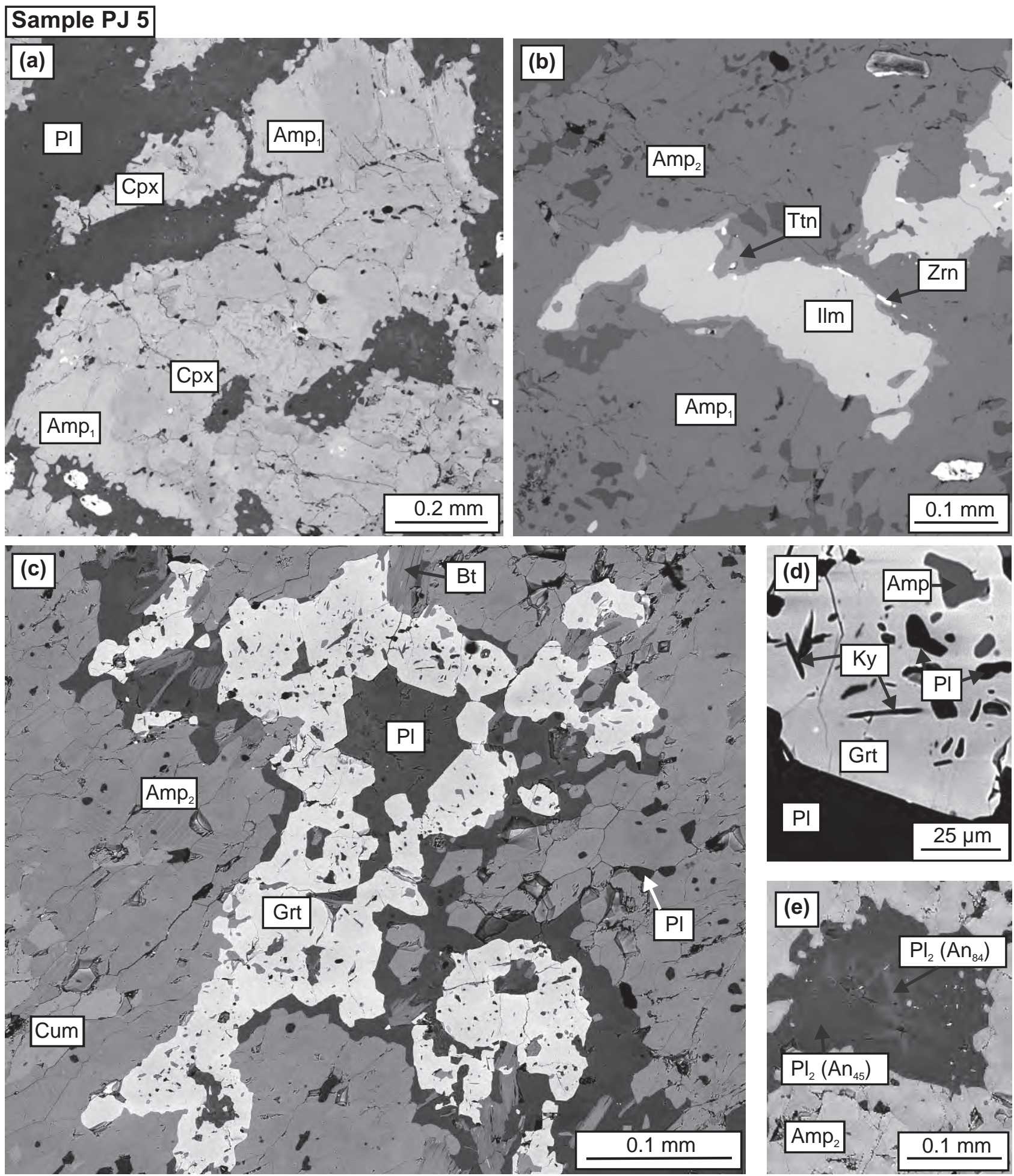

Fig. 2 Back-scattered electron images characterizing the mineral assemblage of the TCC metagabbro: a - Polycrystalline aggregate consisting of clinopyroxene and amphibole in plagioclase matrix; b - Detail of ilmenite grain with titanite rim and zircon grains; $\mathbf{c}-$ Amphibole and garnet corona; $\mathbf{d}$ - Detail of garnet corona with inclusions; $\mathbf{e}$ - Detail of plagioclase recrystallization into bytownite and andesine mixture.

Tab. 2) usually form polycrystalline aggregates (Fig. 2a). These aggregates mostly have clinopyroxene and amphibole crystals in the central parts, and amphibole with ilmenite lamellae at their margins. Biotite grains with $\mathrm{X}_{\mathrm{Mg}}=0.57-0.58$ and $\mathrm{Ti}=2.7-2.9$ apfu (Tab. 2) locally occur in association with ilmenite, which is commonly surrounded by tiny $(<1 \mu \mathrm{m})$ zircon grains (Fig. 2b). 

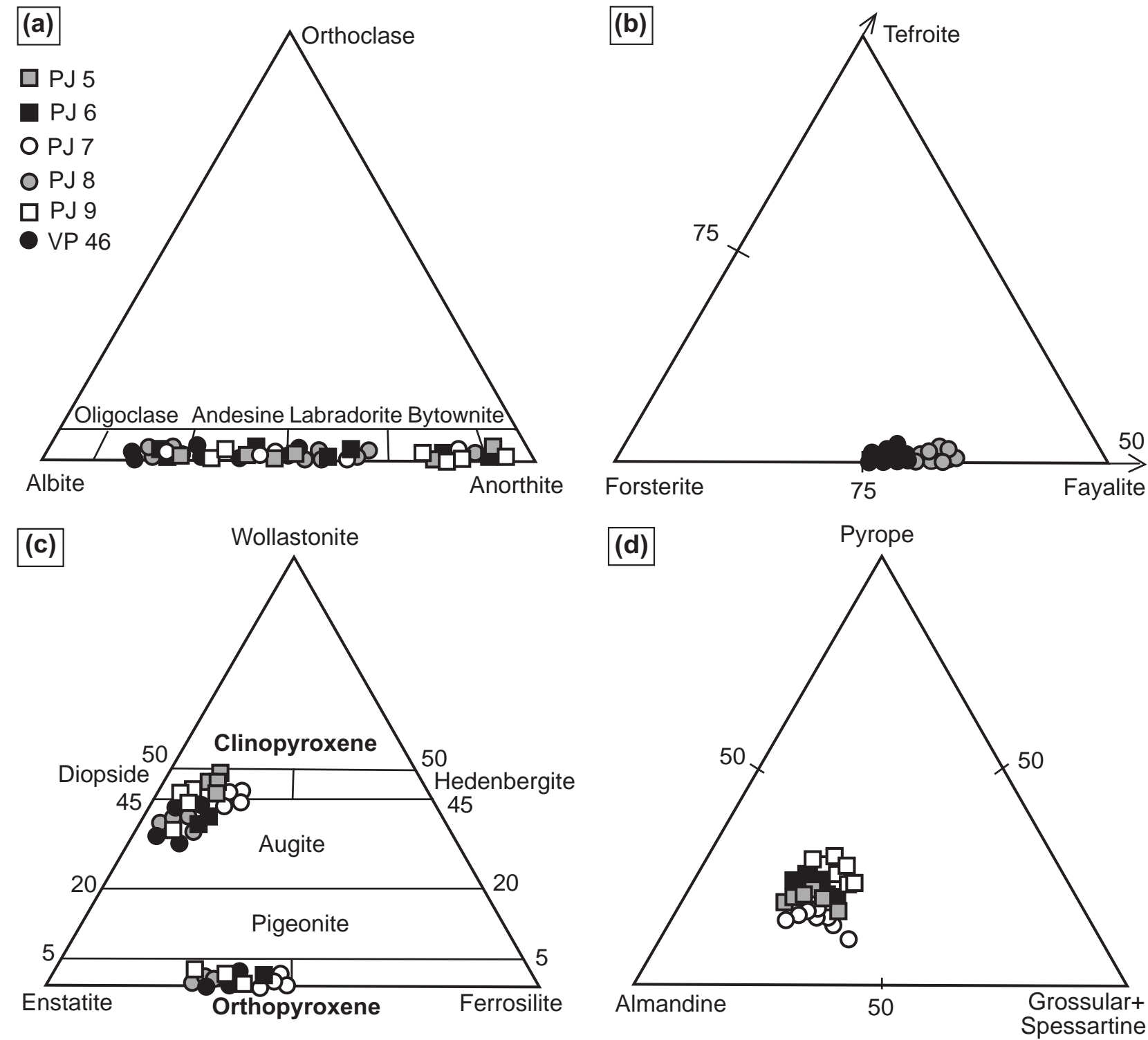

(e)

$$
C \mathrm{a}_{\mathrm{B}}>=1.5 ;(\mathrm{Na}+\mathrm{K})_{\mathrm{A}}>=0.5 ; \mathrm{Ti}<0.5
$$
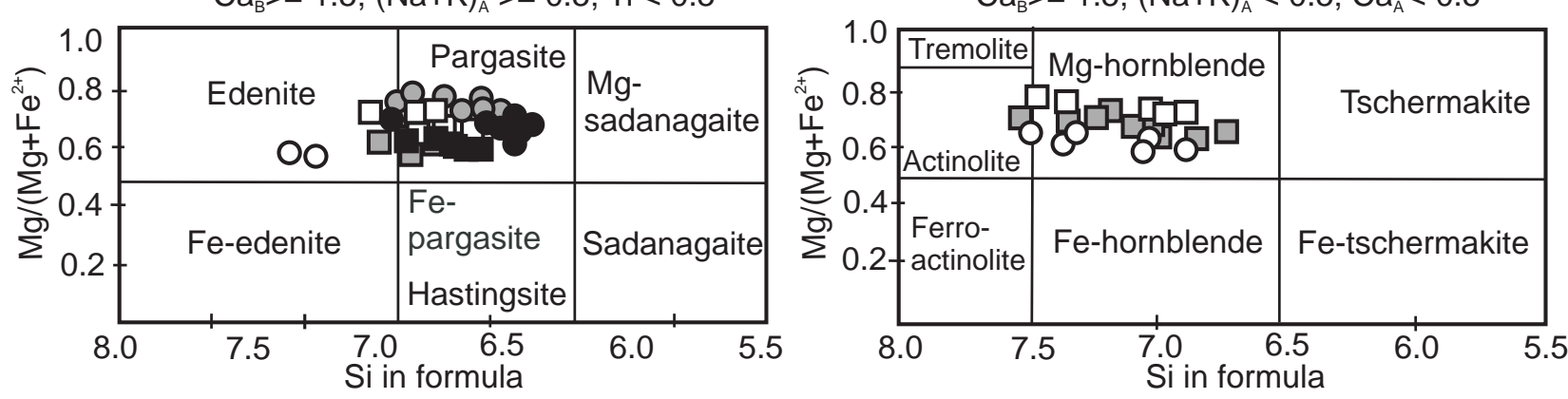

Fig. 3 Diagrams demonstrating composition of the main rock-forming minerals of all samples: olivine (a), plagioclase (b), pyroxenes (c) after Morimoto (1988), garnet (d) and amphibole (e-f) after Leake et al. (1997).

The $\mathrm{M}_{2}$ mineral assemblage is characterized by growth of amphibole, garnet, plagioclase and titanite at the expense of $M_{1}$ minerals, which are enveloped by several types of the corona sequence. The $\mathrm{M}_{1}$ clinopyroxene occurs either alone or it is surrounded by an amphibole corona up to $200 \mu \mathrm{m}$ thick. $M_{1}$ amphibole is rimmed by 


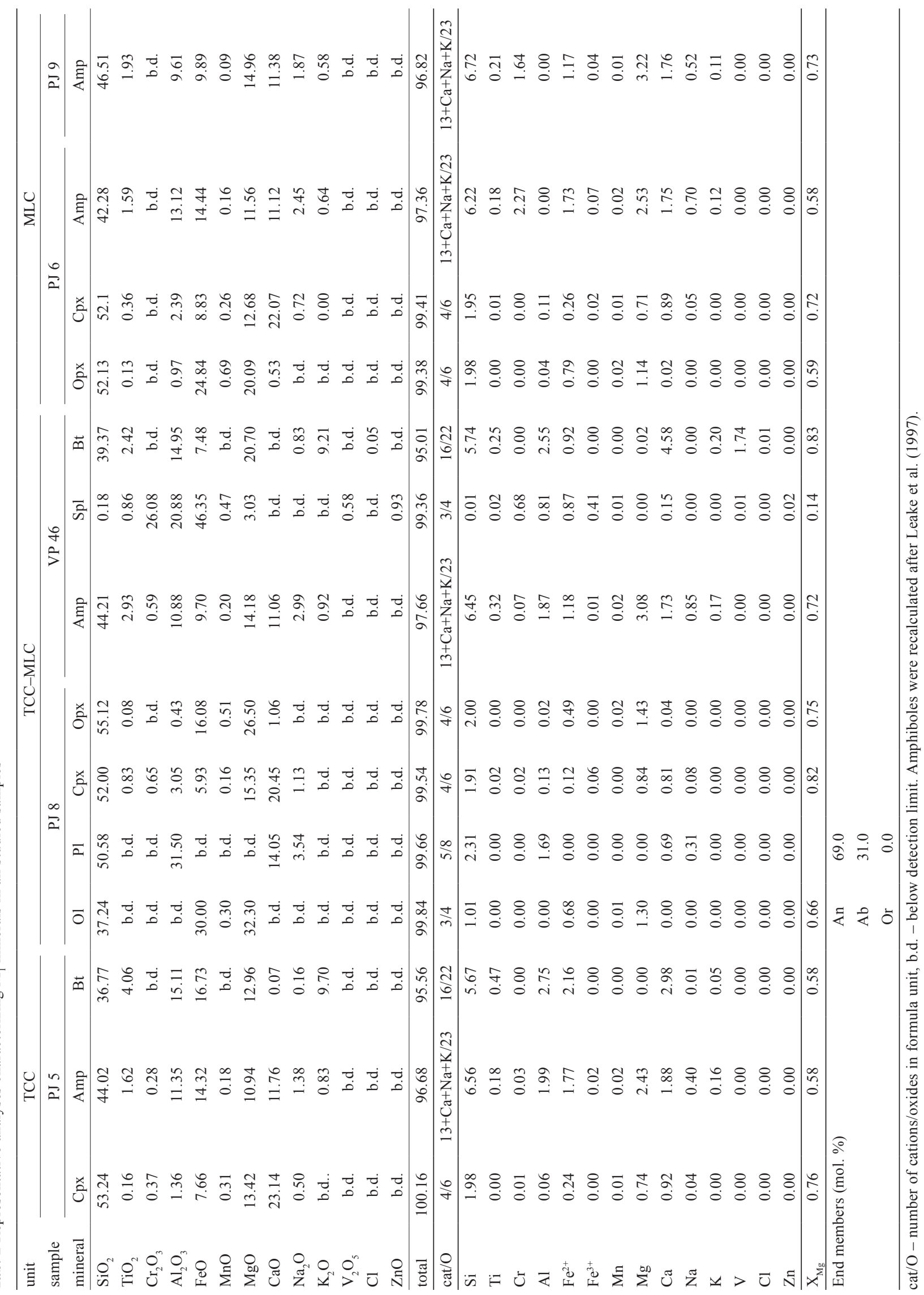




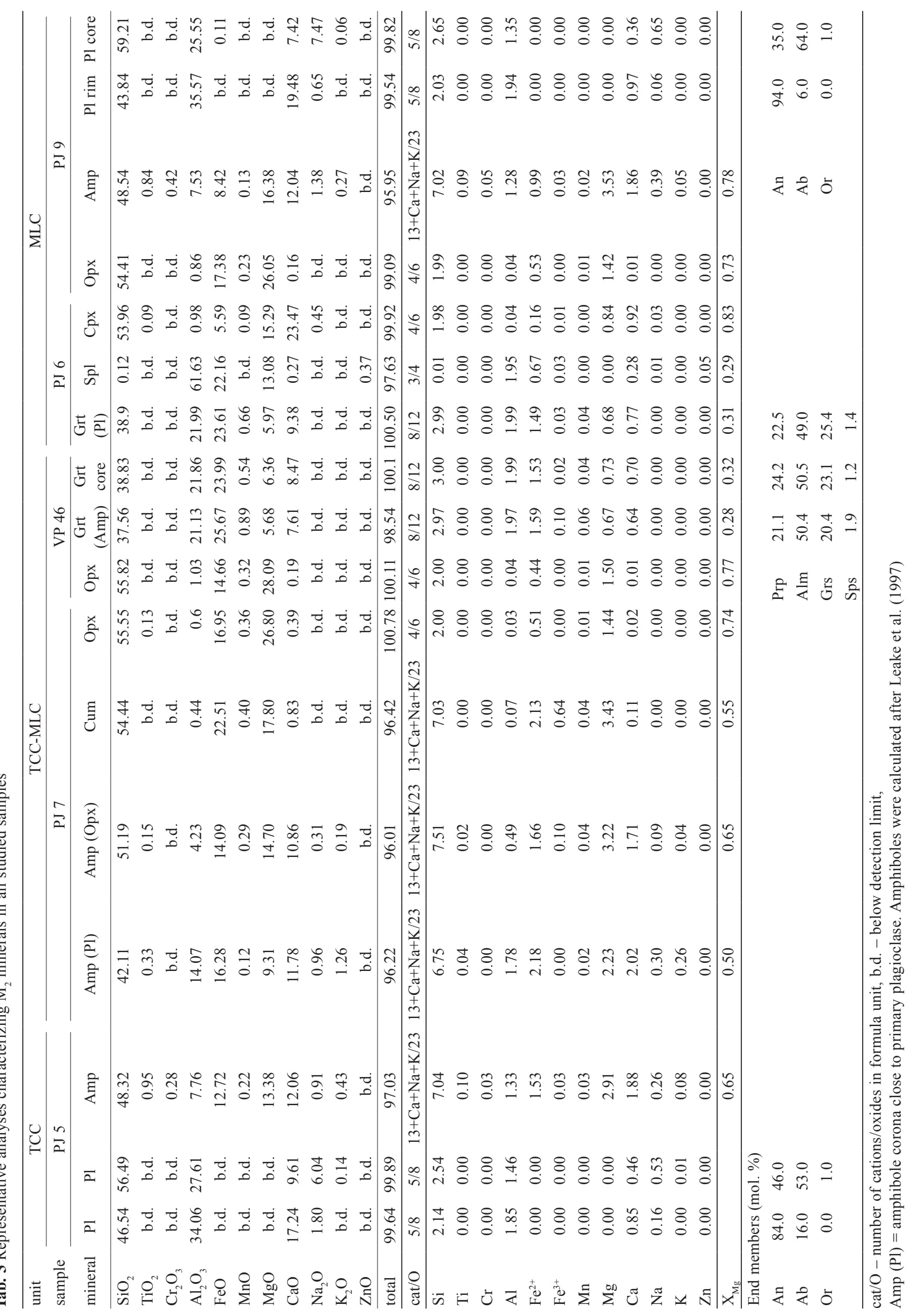


a 50-250 $\mu \mathrm{m}$ thick corona of $\mathrm{M}_{2}$ amphibole, which is locally followed by a $20-200 \mu \mathrm{m}$ thick garnet corona (Fig. 2c). $M_{2}$ amphibole is magnesiohornblende (Fig. 3f, Tab. 3) characterized by an increase in $X_{\mathrm{Mg}}(0.59 \rightarrow 0.67)$, $\mathrm{Si}(6.80 \rightarrow 7.04 \mathrm{apfu})$ and decrease in $\mathrm{Na}(0.33 \rightarrow 0.26), \mathrm{K}$ $(0.14 \rightarrow 0.08), \mathrm{Al}(1.7 \rightarrow 1.3)$ and $\mathrm{Ti}(0.16 \rightarrow 0.10 \mathrm{apfu})$ in the direction from the primary amphibole and clinopyroxene towards the surrounding plagioclase. Garnet corona contains numerous plagioclase and amphibole inclusions up to $40 \mu \mathrm{m}$ across together with small $(<1 \mu \mathrm{m})$ elongated crystals of kyanite (Fig. 2d). Garnet is almandine with composition $\mathrm{Alm}_{52-58} \mathrm{Grs}_{18-22} \operatorname{Prp}_{16-22} \mathrm{Sps}_{2-6}$ (Fig. 3d). Garnet coronas show a slightly asymmetric compositional zoning, with respect to its central part $\left(\mathrm{Alm}_{56} \operatorname{Prp}_{22}\right.$ $\left.\mathrm{Grs}_{18} \mathrm{Sps}_{3} ; \mathrm{X}_{\mathrm{Mg}}=0.28\right)$, characterized by a rimward decrease in $\mathrm{X}_{\mathrm{Mg}}$, Prp and Alm, and increase in Grs and Sps components. The asymmetry is revealed by a more significant chemical change towards the contact with amphibole $\left(\mathrm{Alm}_{54} \operatorname{Prp}_{18} \mathrm{Grs}_{20} \mathrm{Sps}_{4} ; \mathrm{X}_{\mathrm{Mg}}=0.25\right)$ compared to the contact with plagioclase $\left(\mathrm{Alm}_{53} \operatorname{Prp}_{21} \mathrm{Grs}_{22} \mathrm{Sps}_{2} ; \mathrm{X}_{\mathrm{Mg}}\right.$ $=0.28$ ). The primary plagioclase (andesine-labradorite) is extensively replaced by a fine-grained mixture of plagioclase with two distinct compositions, calcic (bytownite; $\mathrm{An}_{85}$ ) and sodic (andesine, $\mathrm{An}_{45}$; Fig. 2e, Tab. 3), whereby the former forms elongated ribbon-like grains in the matrix dominated by the latter (Fig. 2e). Primary ilmenite occurs in association with zircon and it is locally surrounded by a thin titanite rim (Fig. 2b).

Additionally, epidote is occasionally present in the central part of the clinopyroxene and amphibole aggregates together with calcic amphibole (actinolite to hornblende, $\mathrm{X}_{\mathrm{Mg}}=0.67-0.69 ; \mathrm{Si}=7.22-7.54, \mathrm{Ti}=$ $0.02-0.03, \mathrm{~K}=0.03-0.05$ and $\mathrm{Na}=0.16-0.22 \mathrm{apfu})$ and cummingtonite $\left(\mathrm{X}_{\mathrm{Mg}}=0.55-0.56, \mathrm{Si}=7.01-7.03 \mathrm{apfu}\right)$. Plagioclase is in places decomposed into a fine-grained mixture of albite, muscovite and epidote forming narrow zones along the grain margins or cross-cutting the primary plagioclase. Prehnite is locally present in association with titanite; biotite is partially replaced by chlorite.

\subsection{Metagabbros at the contact of the TCC and MLC}

Three samples with best preserved primary mineral assemblage $\mathrm{M}_{1}$ were collected at the contact of TCC and MLC. Two of them, PJ8 and VP46, are olivine metagabbros (Fig. 4). The third sample (PJ7) contains an olivine-free $M_{1}$ mineral assemblage, which includes quartz (Fig. 5).

The $\mathrm{M}_{1}$ assemblage of olivine metagabbro PJ8 consists of plagioclase, olivine, and clinopyroxene with minor biotite and ilmenite, and accessoric apatite and pyrrhotite. Olivine $\left(\mathrm{X}_{\mathrm{Mg}}=0.65-0.71\right.$; Fig. 3b; Tab. 2) forms grains $(<2 \mathrm{~mm})$ with inclusions of $\mathrm{Cr}$-spinel and pyrrhotite. It is commonly crosscut by fractures filled by amphibole or minerals of the serpentine group (Fig. 4a). Plagioclase forms up to $3 \mathrm{~mm}$ large crystals $\left(\mathrm{An}_{56-70}\right.$; Tab. 2). Clinopyroxene (augite, $\mathrm{X}_{\mathrm{Mg}}=0.81-0.86$ and $\mathrm{Jd}=2-5$ mol. \%; Fig. 3c; Tab. 2) occurs as up to $3 \mathrm{~mm}$ large crystals containing inclusions of olivine, ilmenite, and occasionally $\mathrm{Cr}$-spinel. Orthopyroxene (enstatite with $\mathrm{X}_{\mathrm{Mg}}=0.74-0.75$; Fig. 3c; Tab. 2) is present rarely as a part of clinopyroxene-amphibole-olivine aggregates (Fig. 3a) and it contains inclusions of Cr-spinel. Amphibole (pargasite-edenite with $\mathrm{X}_{\mathrm{Mg}}=0.76-0.77, \mathrm{Si}=$ 6.38-6.42 apfu and 0.30-0.36 apfu of Ti) usually occurs within clinopyroxene-orthopyroxene aggregates and is locally surrounded by, or includes tiny $(<1 \mu \mathrm{m})$ crystals of, ilmenite (Fig. 4a). Biotite (phlogopite with $\mathrm{X}_{\mathrm{Mg}}=$ $0.79-0.81$ and $1.81-2.05$ apfu of Ti) forms up to $1 \mathrm{~mm}$ large crystals, which locally contain inclusions of ilmenite. Ilmenite is in places associated with biotite and its rims are commonly surrounded by small zircon crystals.

The $\mathrm{M}_{2}$ mineral assemblage is characterized by the formation of coronas composed of orthopyroxene, amphibole, and spinel around the $\mathrm{M}_{1}$ minerals and by plagioclase recrystallization. Clinopyroxene is surrounded by a single layer of amphibole (pargasite, $\mathrm{X}_{\mathrm{Mg}}=0.70-0.72$, $\mathrm{Si}=5.93-6.03 \mathrm{apfu}$ ). Biotite and olivine grains at the contact with plagioclase are usually enveloped by double corona of orthopyroxene $\left(<100 \mu \mathrm{m}\right.$, enstatite with $\mathrm{X}_{\mathrm{Mg}}=$ $0.70-0.71)$ followed by a layer $(<200 \mu \mathrm{m})$ of amphibole (pargasite with $\mathrm{X}_{\mathrm{Mg}}=0.71-0.73$ ). Amphibole corona occasionally contains embayments of plagioclase and spinel symplectites along the contact with plagioclase (Fig. 4b). Plagioclase is locally recrystallized into a mixture of oligoclase $\left(\mathrm{An}_{24-29}\right)$ and anorthite $\left(\mathrm{An}_{92}\right.$; Fig. 3a), in restricted domains along the rims of primary grains. These domains contain tiny $(0 . \mathrm{X} \mu \mathrm{m})$ spinel grains and small tabular corundum crystals (Fig. 4b).

The second olivine metagabbro, VP46, shows similar primary mineral assemblage as the sample PJ8: olivine, plagioclase, clinopyroxene, amphibole, biotite and ilmenite; however the $M_{1}$ assemblage is less affected by the $\mathrm{M}_{2}$ overprint. Olivine ( $\left.\mathrm{X}_{\mathrm{Mg}}=0.70-0.75\right)$ usually occurs as large crystals (up to $3 \mathrm{~mm}$ in size, Fig. 4c), commonly containing tiny $(<0$.X $\mu \mathrm{m})$ inclusions of calcic amphibole associated with magnetite (Fig. 4c). Plagioclase forms up to $5 \mathrm{~mm}$ large crystals generally not affected by recrystallization (Fig. 4c), which show rather variable composition (Fig. 3d). The plagioclase domains are composed of sectors with contrasting chemistry ranging from oligoclase $\left(\mathrm{An}_{18-25}\right)$ to labradorite $\left(\mathrm{An}_{53}\right.$, Fig. 3a). Clinopyroxene (augite-diopside, $\mathrm{X}_{\mathrm{Mg}}=0.77-0.80$ and Jd 3-7 mol. \%) forms euhedral crystals $(<1 \mathrm{~mm})$ with spinel inclusions. Clinopyroxene shows compositional zoning (Fig. 6a) with distinct trends determined by the particular $M_{1}$ phase at the contact. The clinopyroxene cores are relatively 


\section{Sample PJ 8}

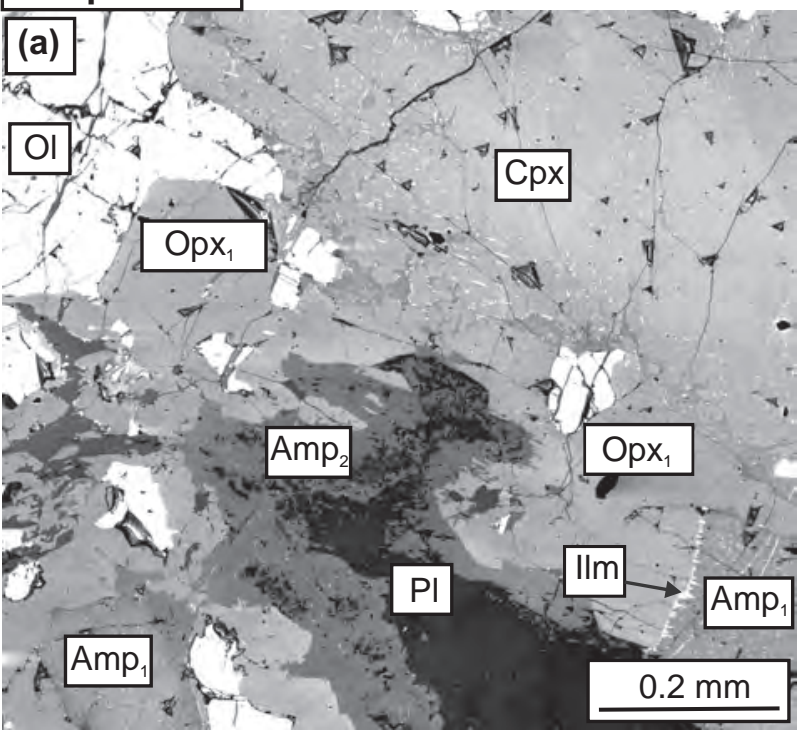

\section{Sample VP 46}
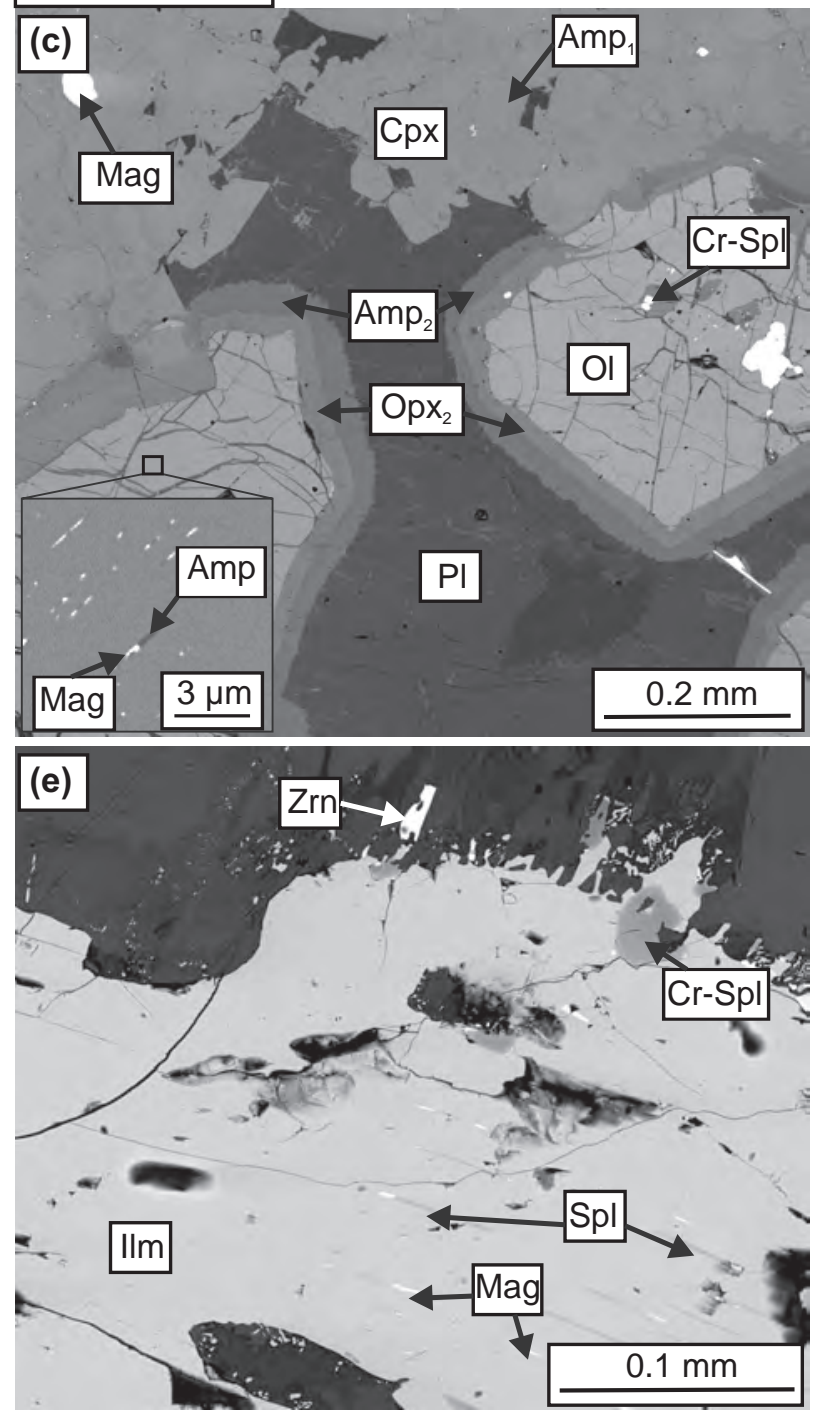
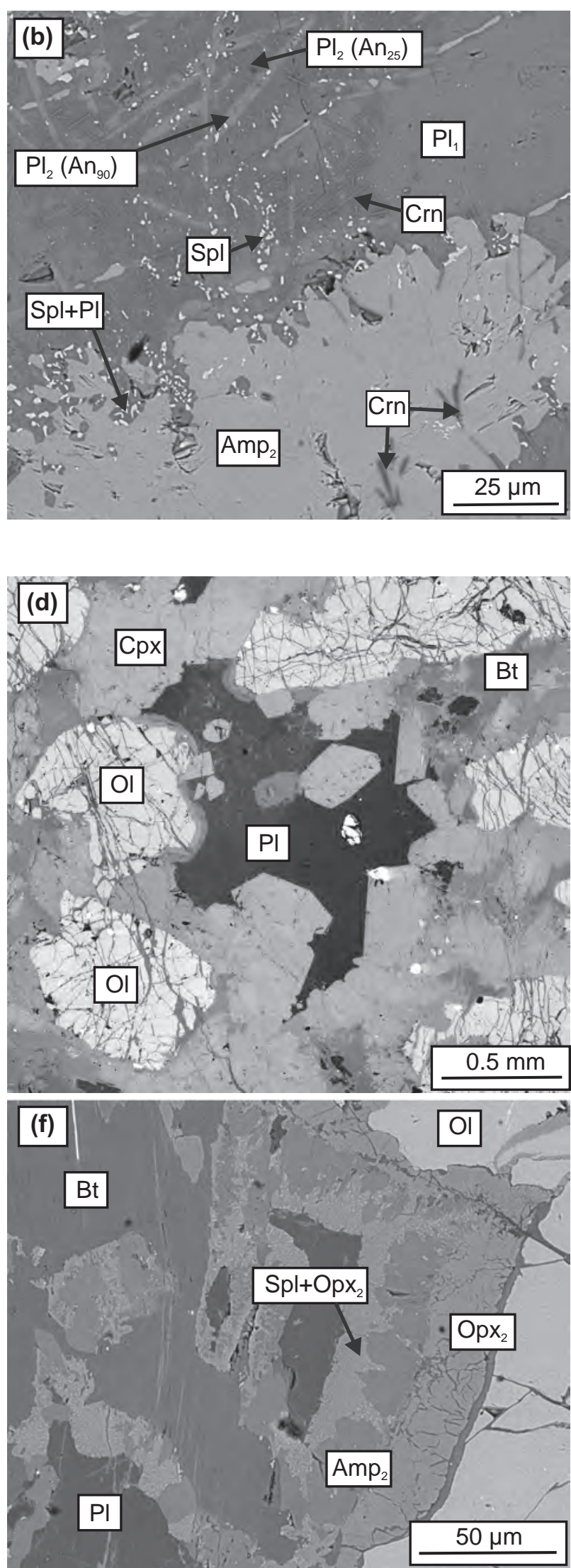

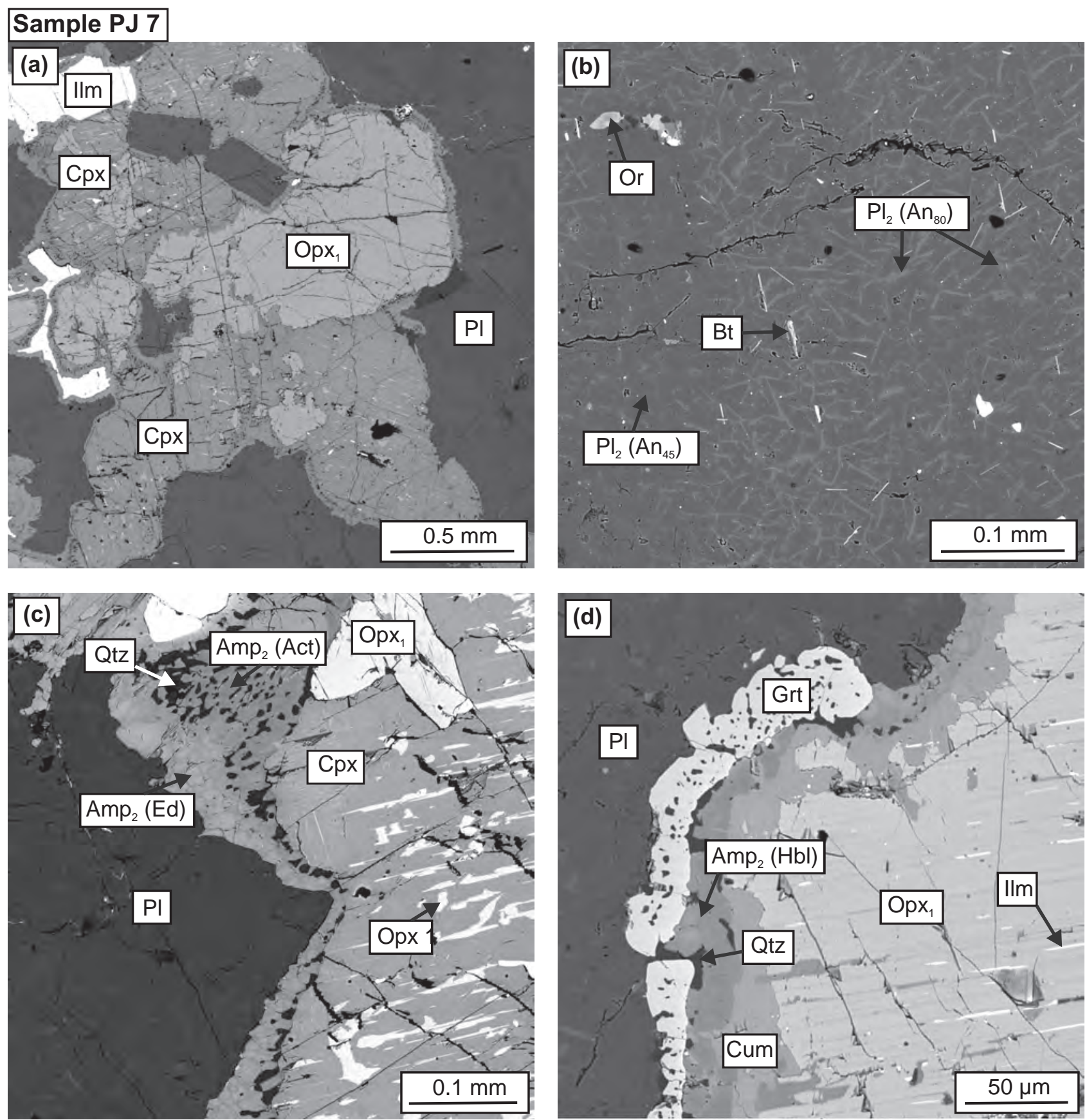

Fig. 5 Back-scattered electron images characterizing the mineral assemblage of the olivine-free metagabbro from the TCC-MLC boundary. a Primary magmatic texture defined by large orthopyroxene, clinopyroxene, ilmenite, and plagioclase; $\mathbf{b}$ - Detail of plagioclase recrystallized into mixture of bytownite and andesine, including small grains of biotite; $\mathbf{c}$ - Detail of double corona around clinopyroxene formed by quartz-calcic amphibole symplectite followed by monomineral amphibole layer; $\mathbf{d}$ - Detail of orthopyroxene with ilmenite inclusions enveloped by triple corona of 1) cummingtonite, 2) calcic amphibole (actinolite) with quartz and 3) garnet layer.

Fig. 4 Back-scattered electron images characterizing the mineral assemblage of the olivine-bearing metagabbros from the TCC-MLC boundary: $\mathbf{a}$ - Detail of primary olivine, clinopyroxene, amphibole $\left(\mathrm{Amp}_{1}\right)$, and orthopyroxene $\left(\mathrm{Opx}_{1}\right)$ surrounded by amphibole corona; $\mathbf{b}-\mathrm{Detail}$ of amphibole corona with symplectite consisting of plagioclase and spinel; in the upper part of the picture recrystallization of plagioclase into anorthite and oligoclase with spinel and corundum; c - Primary clinopyroxene, amphibole and olivine enveloped by orthopyroxene and amphibole coronas; in bottom left corner detail of inclusions in olivine of magnetite associated with amphibole; $\mathbf{d}$ - Detail of ilmenite grain with magnetite and spinel lamellae, which is surrounded by symplectite-like texture accompanied by zircon grains; $\mathbf{e}$ - Corona sequences around olivine represented by orthopyroxene and amphibole layers alternating with spinel-plagioclase symplectite; primary biotite is surrounded by amphibole alternating with spinel-plagioclase symplectite. 


\section{Sample VP 46}
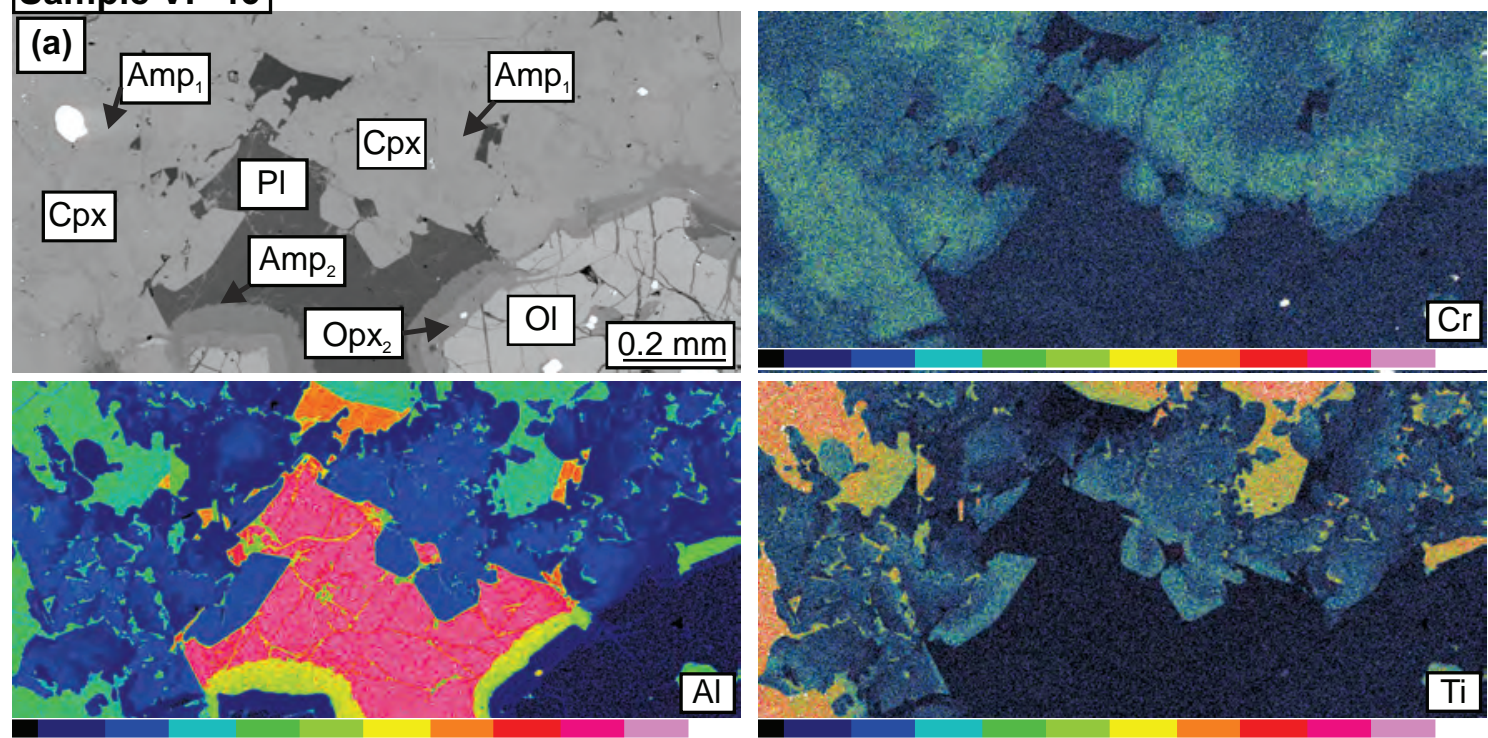

\section{Sample PJ 7}
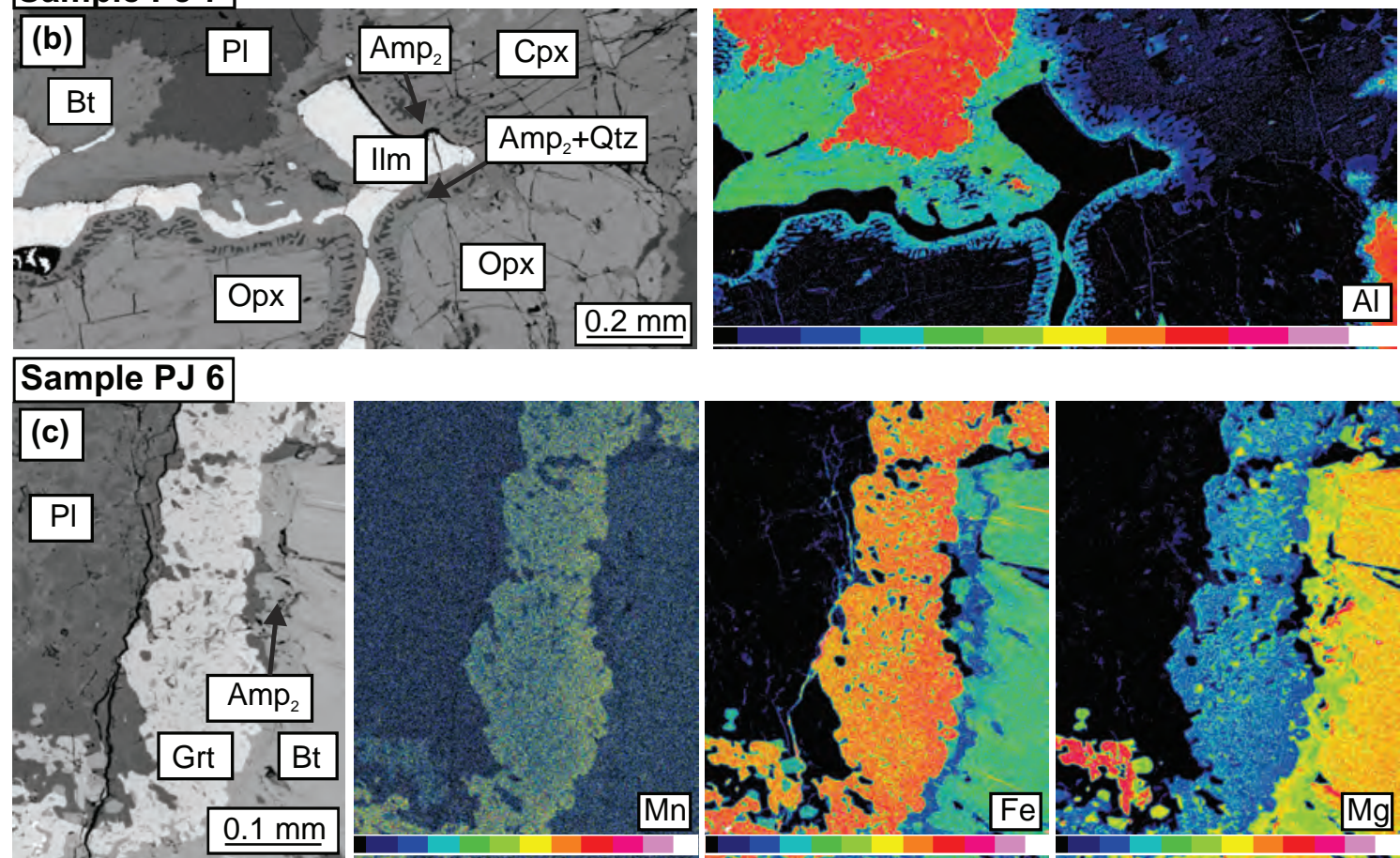

\section{Sample PJ 9}
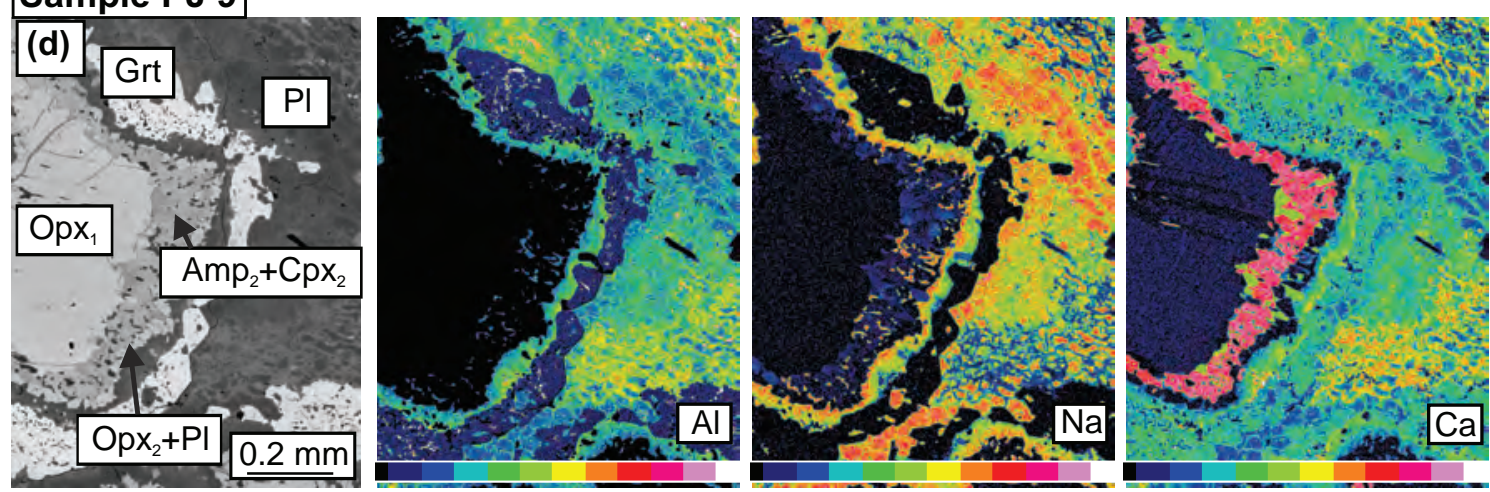
rich in $\mathrm{Cr}(\mathrm{Cr}=0.04, \mathrm{Na}=0.07, \mathrm{Al}=0.18, \mathrm{Ti}=0.03$ and $\mathrm{Ca}=0.77 \mathrm{apfu} ; \mathrm{X}_{\mathrm{Mg}}=0.80$ ). The zoning towards the contact with plagioclase is characterized by a decrease in $\mathrm{Cr}, \mathrm{Na}, \mathrm{Ca}$ and $\mathrm{X}_{\mathrm{Mg}}$ and an increase in $\mathrm{Ti}$ and $\mathrm{Al}(\mathrm{Cr}$ $=0.01, \mathrm{Na}=0.05, \mathrm{Al}=0.24, \mathrm{Ti}=0.05$, and $\mathrm{Ca}=0.76$ apfu; $\left.\mathrm{X}_{\mathrm{Mg}}=0.77\right)$. In contrast, towards the contact with $\mathrm{M}_{1}$ amphibole the zoning shows a decrease in $\mathrm{Cr}, \mathrm{Na}, \mathrm{Al}$, $\mathrm{Ti}, \mathrm{Ca}$, and $\mathrm{X}_{\mathrm{Mg}}$ and an increase in $\mathrm{Ca}(\mathrm{Cr}=0.01, \mathrm{Na}=$ $0.04, \mathrm{Al}=0.06, \mathrm{Ti}=0.01$ and $\left.\mathrm{Ca}=0.80 \mathrm{apfu} ; \mathrm{X}_{\mathrm{Mg}}=0.79\right)$. Orthopyroxene (enstatite, $\mathrm{X}_{\mathrm{Mg}}=0.70-0.78$ ) is observed occasionally between olivine and biotite grains and it contains inclusions of ilmenite and spinel. Anhedral crystals of amphibole (pargasite-edenite; Fig. 3e, Tab. 3) are associated with clinopyroxene (Fig. 4c) and they reveal compositional zoning (Fig. 6a) with a rimward decrease in $\mathrm{Ti}, \mathrm{Al}$ and $\mathrm{Na}$ contents accompanied by an increase in $\mathrm{Cr}$, Si and $\mathrm{X}_{\mathrm{Mg}}(\mathrm{Ti}=0.58 \rightarrow 0.32, \mathrm{Al}=1.99 \rightarrow 1.87, \mathrm{Na}=$ $0.92 \rightarrow 0.85, \mathrm{Cr}=0.05 \rightarrow 0.07, \mathrm{Si}=6.23 \rightarrow 6.51 \mathrm{apfu}, \mathrm{X}_{\mathrm{Mg}}$ $=0.70 \rightarrow 0.72$ ). Biotite (phlogopite, $X_{\mathrm{Mg}}=0.80-0.85$ with highly variable Ti of $0.75-3.04 \mathrm{apfu}$; Tab. 2) forms up to $0.5 \mathrm{~mm}$ large crystals with inclusions of ilmenite observed between olivine grains. Ilmenite commonly occurs in association with $\mathrm{Cr}$-spinel $(\mathrm{Cr}=0.48-0.68 \mathrm{apfu}$; Tab. 2 ) and magnetite, which can also form lamellae inside ilmenite crystals (Fig. 4d). Ilmenite is usually rimmed by small zircon crystals (Fig. 4d).

The $\mathrm{M}_{2}$ mineral assemblage is connected with formation of coronas including orthopyroxene, amphibole, and spinel. Olivine is surrounded by double corona consisting of up to $100 \mu \mathrm{m}$ wide orthopyroxene domain (enstatite with $\mathrm{X}_{\mathrm{Mg}}=0.76-0.78$; Fig. 3c; Tab. 3) followed by $10-60 \mu \mathrm{m}$ wide corona of amphibole (pargasite, $\mathrm{X}_{\mathrm{Mg}}=$ $0.74-0.79, \mathrm{Si}=5.63-6.01 \mathrm{apfu}$ ), which is occasionally alternating with an orthopyroxene-spinel symplectite (Fig. 4c, e). No corona occurs around clinopyroxene or amphibole. The contact between biotite and plagioclase is marked by a symplectitic corona (5-25 $\mu \mathrm{m}$ thick) of spinel and orthopyroxene, which is in places alternating with amphibole corona (pargasite, $\mathrm{X}_{\mathrm{Mg}}=0.77$; Fig. 4f).

Sample PJ7 is the only one that contains quartz as a part of the primary mineral assemblage: plagioclase, clinopyroxene, orthopyroxene, ilmenite, biotite and quartz (Fig. 5a). In addition, this sample is generally 它

Fig. 6 Compositional maps characterizing the representative minerals. a - Zoning of clinopyroxene, amphibole and corona sequence around olivine in the olivine-bearing sample VP 46 from the TCC-MLC boundary: BSE picture of the analysed area (left) and distributions of $\mathrm{Cr}$, Al, and Ti (right); b - Zoning of amphibole + quartz symplectite and monomineral amphibole corona around clinopyroxene in sample PJ 7 from the TCC-MLC boundary: BSE image, Al distribution; $\mathbf{c}-$ Zoning of garnet corona between primary biotite and recrystallized plagioclase in the MLC sample PJ 6: BSE image, Mn, Fe, and Mg distributions; d - Corona sequence around orthopyroxene and character of plagioclase recrystallization into fine-grained matrix in the MLC sample PJ 9: BSE image, $\mathrm{Al}, \mathrm{Na}$, and $\mathrm{Ca}$ distributions. richer in ilmenite and plagioclase compared to the other samples. Although large crystals of the primary plagioclase preserve their original crystal shapes with twinning still recognizable, they recrystallized completely into the fine-grained mixture of sodic and calcic plagioclase. The integrated original composition corresponds to labradorite $\left(\mathrm{An}_{60}\right)$. Clinopyroxene containing orthopyroxene and ilmenite lamellae (augite-diopside, $\mathrm{X}_{\mathrm{Mg}}=0.67$ and $\mathrm{Jd}=$ 2.3-2.7 mol. \%; Fig. 3c) and orthopyroxene with lamellae of clinopyroxene and ilmenite (enstatite with $\mathrm{X}_{\mathrm{Mg}}=$ $0.51-0.56$ ) form crystals up to $3 \mathrm{~mm}$ across (Fig. 5a). Large orthopyroxene grains show slight compositional zoning with $\mathrm{X}_{\mathrm{Mg}}$ decreasing from 0.55 to 0.52 towards their rims. Ilmenite (Fig. 5a) is usually associated with both pyroxenes and biotite and forms anhedral crystals up to $1 \mathrm{~mm}$ that are usually surrounded by small $(<3 \mu \mathrm{m})$ zircon crystals.

The $\mathrm{M}_{2}$ mineral assemblage is associated with formation of coronas composed of garnet and compositionally variable amphibole (Fig. 3e-f) and with recrystallization of the $M_{1}$ plagioclase. The primary ilmenite is surrounded by up to $100 \mu \mathrm{m}$ wide garnet corona with inclusions of amphibole, dolomite, quartz, and kyanite. Garnet has a composition of $\mathrm{Alm}_{55-59} \mathrm{Grs}_{18-28} \operatorname{Prp}_{15-17} \mathrm{Sps}_{3-4}$ (Fig. 3d) and shows compositional zoning characterized by increasing Alm, Prp and Sps, and decreasing Grs contents from core to the rim. The zoning is slightly asymmetric with more significant compositional change towards the contact with ilmenite compared to the contact with plagioclase (ilmenite $\rightarrow$ plagioclase: $\mathrm{Alm}_{58 \rightarrow 51 \rightarrow 56} \operatorname{Prp}_{15 \rightarrow 14 \rightarrow 17} \mathrm{Grs}_{18 \rightarrow 28}$ $\rightarrow 21 \mathrm{Sps}_{4 \rightarrow 3 \rightarrow 4} ; \mathrm{X}_{\mathrm{Mg}}=20 \rightarrow 21 \rightarrow 22$ ). Occasionally, a narrow corona of amphibole is present between ilmenite and the garnet domain. Clinopyroxene is enveloped by a double corona composed of a $10-100 \mu \mathrm{m}$ thick symplectite layer consisting of amphibole and quartz that is followed by a monomineral amphibole layer up to $100 \mu \mathrm{m}$ in width (Fig. 5c). The systematic change in amphibole composition (Fig. 6b) is demonstrated by a continual decrease of $\mathrm{X}_{\mathrm{Mg}}$ and an increase in $\mathrm{Al}, \mathrm{Ca}, \mathrm{K}$, and $\mathrm{Na}$ towards plagioclase in both amphibole-quartz symplectite layer (actinolite-magnesiohornblende; $\mathrm{X}_{\mathrm{Mg}}$ $=0.65 \rightarrow 0.61 ; \mathrm{Si}=7.51 \rightarrow 7.24, \mathrm{Al}=0.49 \rightarrow 0.94, \mathrm{Ca} \stackrel{\mathrm{Mg}}{=}$ $1.78 \rightarrow 1.90, \mathrm{Na}=0.09 \rightarrow 0.20$ and $\mathrm{K}=0.04 \rightarrow 0.09 \mathrm{apfu})$ and the outer monomineralic amphibole zone (edenite; $\mathrm{X}_{\mathrm{Mg}}=0.60 \rightarrow 0.51 ; \mathrm{Si}=7.28 \rightarrow 6.75, \mathrm{Al}=0.98 \rightarrow 1.78, \mathrm{Ca}$ $=1.95 \rightarrow 2.02, \mathrm{Na}=0.18 \rightarrow 0.3$ and $\mathrm{K}=0.11 \rightarrow 0.25 \mathrm{apfu}$ ). The garnet corona is locally developed at the contact of the $\mathrm{M}_{2}$ amphibole with plagioclase. The most complex corona sequence is developed around the primary orthopyroxene. In the direction from orthopyroxene to plagioclase, the multiple corona consists of cummingtonite domain $\left(\mathrm{X}_{\mathrm{Mg}}=0.55 ; \mathrm{Si}=6.97-7.03\right.$; Tab. 3), symplectite layer of amphibole (hornblende with $\mathrm{X}_{\mathrm{Mg}}$ $=0.65, \mathrm{Si}=7.28 \mathrm{apfu}$ ) and quartz, followed by garnet 
layer with amphibole, quartz, and kyanite inclusions (Fig. 5d). This garnet corona shows asymmetric compositional zoning generally identical to that formed around ilmenite. The primary plagioclase is decomposed into a fine-grained mixture of andesine $\left(\mathrm{An}_{41-50}\right)$ and bytownite $\left(\mathrm{An}_{80}\right.$; Figs $\left.3 \mathrm{a} ; 5 \mathrm{~b}\right)$, the latter forming small elongated crystals embedded in the andesine matrix. Ilmenite, biotite, amphibole, and quartz occur within the recrystallized plagioclase matrix.

\subsection{Metagabbros from the MLC}

Metagabbros from the MLC, represented by samples PJ6 and PJ9 collected at Otročín and Výškovice, are characterized by the relatively intense recrystallization of the primary minerals; however the primary microstructure is still recognizable. In both samples, the primary mineral assemblage $M_{1}$ includes plagioclase, clinopyroxene, orthopyroxene, amphibole, biotite, and ilmenite, although the degree of recrystallization is different.

In sample PJ6, plagioclase (labradorite, $\mathrm{An}_{65-67}$ ) is intensively recrystallized. Clinopyroxene (augite, $\mathrm{X}_{\mathrm{Mg}}=$ 0.71-0.82 and Jd =5-7 mol. \%; Fig. 3c; Tab. 2) occurs as large $(<2 \mathrm{~mm})$ crystals containing numerous lamellae of orthopyroxene and ilmenite. Orthopyroxene (enstatite, $\mathrm{X}_{\mathrm{Mg}}=0.57-0.59$; Fig. 3c; Tab. 2) forms individual grains up to $0.5 \mathrm{~mm}$ across (Fig. 5a). Amphibole (pargasite; $\mathrm{X}_{\mathrm{Mg}}=0.58-0.65 ; \mathrm{Si}=6.04-6.40$ apfu; Fig. 3e; Tab. 2) occurs as crystals up to $0.4 \mathrm{~mm}$ large (Fig. 7a). Biotite (with $\mathrm{X}_{\mathrm{Mg}}=0.62-0.68$ and $\mathrm{Ti}=0.24-0.55 \mathrm{apfu}$ ) is usually observed in association with ilmenite, the latter forming large grains (up to $1 \mathrm{~mm}$ ) commonly surrounded by small crystals of zircon.

The $\mathrm{M}_{2}$ mineral assemblage connected with recrystallization of the $M_{1}$ assemblage and formation of coronitic and symplectitic texture around primary minerals is represented by plagioclase, orthopyroxene, amphibole, and garnet. Similarly to the other samples, plagioclase is decomposed into a mixture of elongated crystals of bytownite-anorthite $\left(\mathrm{An}_{83-91}\right)$ with random orientation embedded in matrix formed by oligoclase-andesine $\left(\mathrm{An}_{28-47}\right.$; Fig. 3a). This microstructure occurs preferentially in the central parts of the large plagioclase crystals together with small spinel grains (Fig. 7b, Tab. 3). Clinopyroxene is usually surrounded by amphibole (pargasite, $\mathrm{X}_{\mathrm{Mg}}=$ $0.54-0.58, \mathrm{Si}=5.90-6.08 \mathrm{apfu}$ ) corona, $10-100 \mu \mathrm{m}$ in width. However at the contact with plagioclase, it is often enveloped by symplectites formed by amphibole-plagioclase or orthopyroxene-plagioclase. Similarly to clinopyroxene, the primary amphibole and orthopyroxene are enveloped by orthopyroxene-plagioclase or amphiboleplagioclase symplectites (Fig. 7a). Locally, the amphibole zone around orthopyroxene and biotite is followed by a garnet corona containing inclusions of plagioclase, am- phibole, kyanite, and occasionally clinopyroxene. Garnet is dominated by the almandine component $\left(\mathrm{Alm}_{50} \operatorname{Prp}_{20-26}\right.$ $\mathrm{Grs}_{20-26} \mathrm{Sps}_{1-2}$; Fig. 3d). This corona is characterized by a slight asymmetric zoning (Fig. 6c, Tab. 3) characterized by a rimward decrease in $\mathrm{X}_{\mathrm{Mg}}$, Alm and Prp components and, more significant, decrease in Prp and $\mathrm{X}_{\mathrm{Mg}}$ towards the contact with amphibole. The Grs content continuously increases while Sps decreases across the corona from amphibole towards plagioclase $\left(\mathrm{Alm}_{50 \rightarrow 51 \rightarrow 49} \operatorname{Prp}_{21 \rightarrow 24 \rightarrow 23}\right.$ $\left.\mathrm{Grs}_{20 \rightarrow 23 \rightarrow 25} \mathrm{Sps}_{2 \rightarrow 1 \rightarrow 1} ; \mathrm{X}_{\mathrm{Mg}}=0.28 \rightarrow 0.32 \rightarrow 0.31\right)$.

The primary mineral assemblage $\mathrm{M}_{1}$ in sample PJ9 consists of clinopyroxene and orthopyroxene that are surrounded by plagioclase matrix. Plagioclase is completely recrystallized, but it still preserves its euhedral shape especially when locked in pyroxene (Fig. 7c). Clinopyroxene (augite-diopside, $\mathrm{X}_{\mathrm{Mg}}=0.79-0.80, \mathrm{Jd}=3-10$ mol. \%; Fig. 3c) forms up to $3 \mathrm{~mm}$ large crystals with orthopyroxene lamellae and inclusions of amphibole. The orthopyroxene (enstatite, $X_{\mathrm{Mg}}=0.67-0.73$ ) grains up to $1 \mathrm{~mm}$ across contain clinopyroxene lamellae and inclusions of amphibole, apatite, and rutile. Amphibole (pargasite-edenite, $\mathrm{X}_{\mathrm{Mg}}=0.70-0.73, \mathrm{Si}=6.44-6.72$ apfu) occurs usually in association with orthopyroxene or clinopyroxene and occasionally contains inclusions of apatite and rutile. Ilmenite is mostly associated with biotite and it is usually surrounded by zircon and locally replaced by rutile (Fig. 7d).

Several types of coronas were formed around primary minerals in PJ9. Clinopyroxene is mostly surrounded by a narrow (20-60 $\mu \mathrm{m}$ thick) layer of amphibole (Fig. 7c) showing compositional zoning from magnesiohornblende at the contact with clinopyroxene to edenite next to plagioclase (Fig. 3e-f). This change is accompanied by a decrease of $\mathrm{X}_{\mathrm{Mg}}$, $\mathrm{Si}$ and an increase of $\mathrm{Ti}, \mathrm{K}$ and $\mathrm{Na}\left(\mathrm{X}_{\mathrm{Mg}}\right.$ $=0.78 \rightarrow 0.68 ; \mathrm{Si}=7.02-6.17 \mathrm{apfu}, \mathrm{Ti}=0.09 \rightarrow 0.17$, $\mathrm{Na}=0.39 \rightarrow 0.67$ and $\mathrm{K}=0.05 \rightarrow 0.14$ apfu, Tab. 3). Orthopyroxene is enveloped by a complex corona sequence (Fig. 7e). In the direction from orthopyroxene to plagioclase, $30-200 \mu \mathrm{m}$ thick zone of mixed amphibole (magnesiohornblende, $\mathrm{X}_{\mathrm{Mg}}=0.75-0.83 ; \mathrm{Si}=6.83-7.44$ apfu; Fig. 3f) and clinopyroxene (augite-diopside, $\mathrm{X}_{\mathrm{Mg}}$ $=0.82-0.84$ and $\mathrm{Jd}=14-18$ mol. \%; Fig. $3 \mathrm{c}$ ) is followed by $40-200 \mu \mathrm{m}$ thick domain of orthopyroxene-plagioclase symplectite and the sequence is completed by up

Fig. 7 Back-scattered electron images characterizing the mineral assemblage of the MCC metagabbro. a - Magmatic amphibole with orthopyroxene and plagioclase; $\mathbf{b}$ - Detail of primary magmatic plagioclase breakdown into andesine and bytownite with spinel; c - Detail of plagioclase inclusion in clinopyroxene with amphibole corona developed at the contact of both minerals; $\mathbf{d}$ - Detail of an ilmenite grain, partially replaced by rutile and accompanied by small zircon grains; $\mathbf{e}$ - Corona sequence surrounding orthopyroxene consisting of clinopyroxene and amphibole layer followed by orthopyroxene-plagioclase symplectite and garnet layer; $\mathbf{f}$ - Primary plagioclase recrystallized into fine-grained matter with spinel, corundum, and kyanite grains. 


\section{Sample PJ 6}
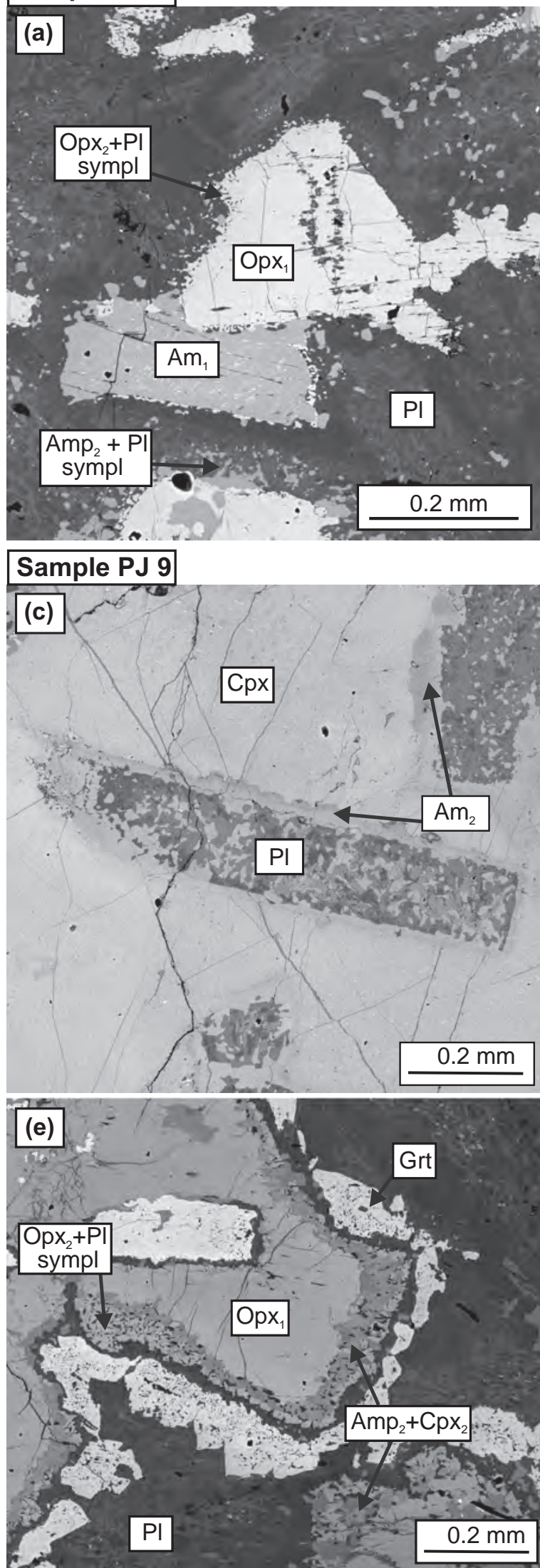
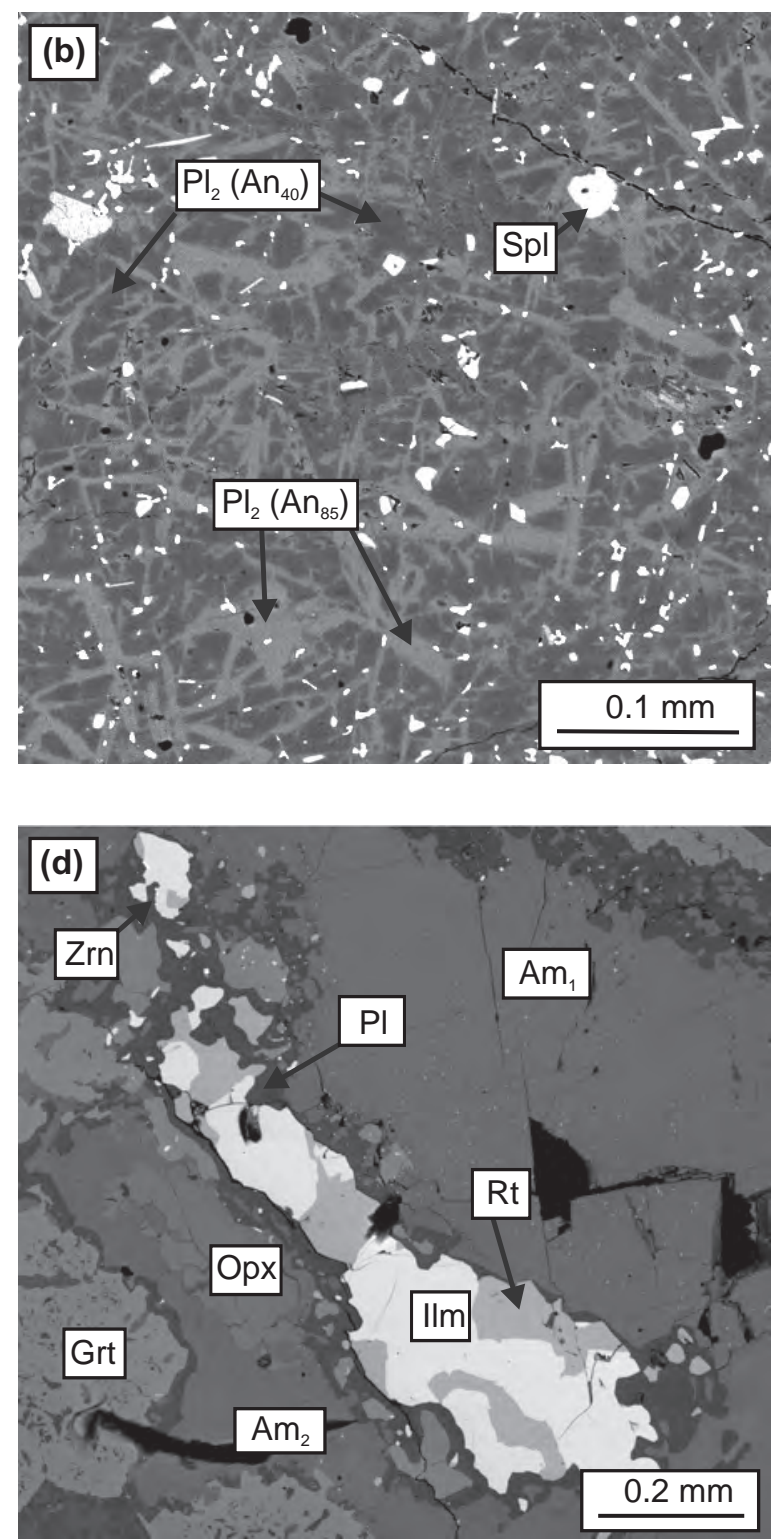

(f)

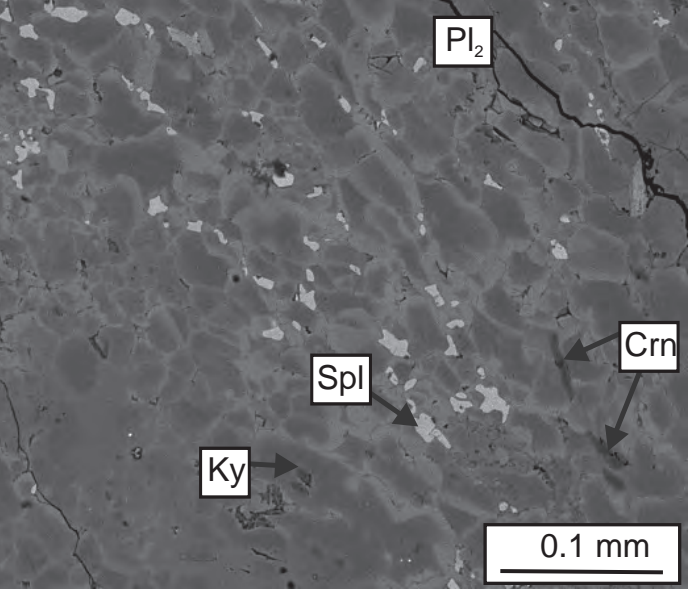




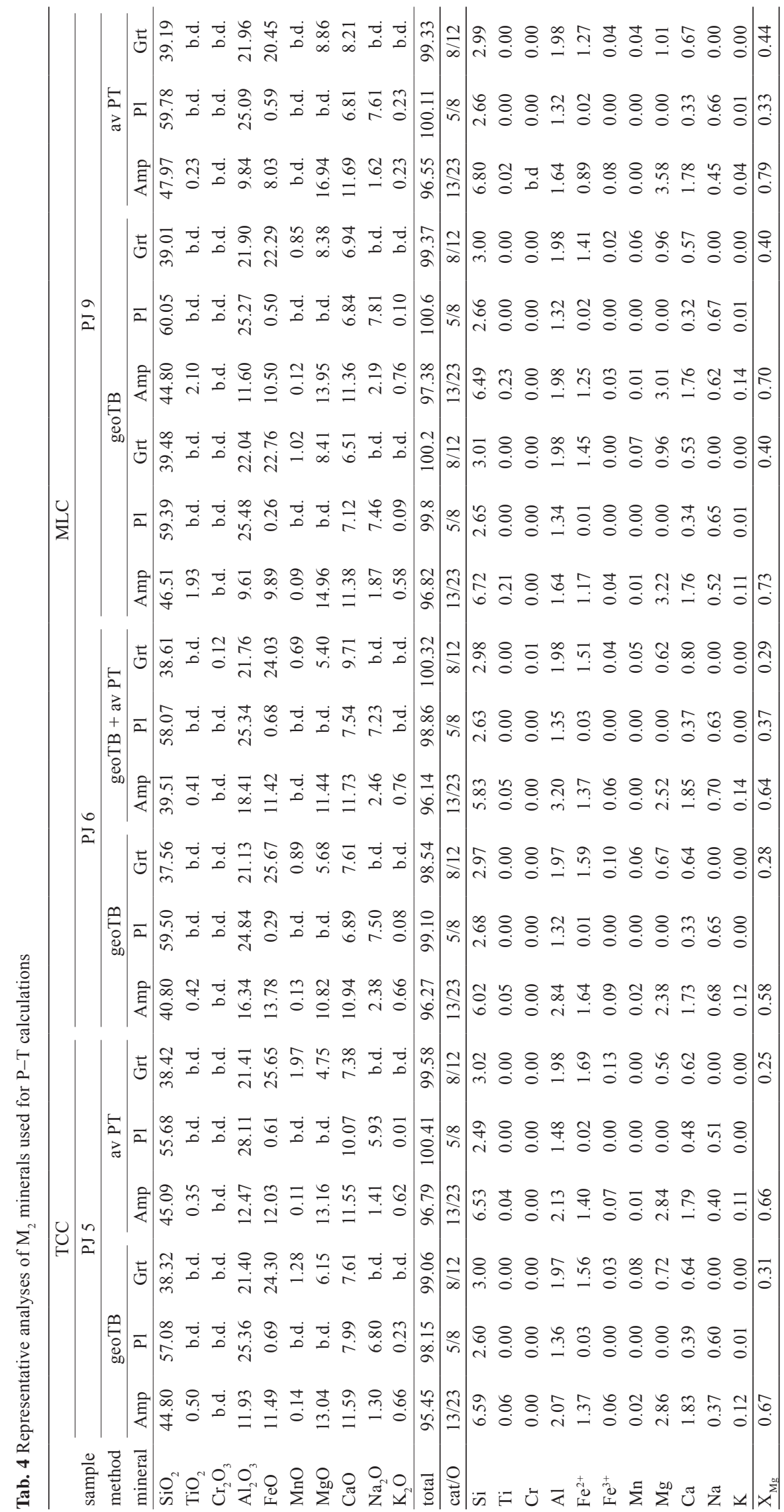

to $300 \mu \mathrm{m}$ wide garnet corona with inclusions of plagioclase, amphibole, and kyanite. Garnet in coronas has a composition of $\mathrm{Alm}_{39-48} \operatorname{Prp}_{29-34} \mathrm{Grs}_{18-26} \mathrm{Sps}_{1-2}$ (Fig. 3d). Garnet coronas show asymmetric zoning with increasing Prp and decreasing Grs proportions from core to rim. The Alm and Sps contents continuously decrease and $\mathrm{X}_{\mathrm{Mg}}$ increases across the corona in the direction from orthopyroxene to plagioclase $\left(\mathrm{Alm}_{48 \rightarrow 41 \rightarrow 40} \operatorname{Prp}_{31 \rightarrow 29 \rightarrow 35}\right.$ $\operatorname{Grs}_{18 \rightarrow 26 \rightarrow 22} \mathrm{Sps}_{2 \rightarrow 1 \rightarrow 1} ; \mathrm{X}_{\mathrm{Mg}}=$ $0.41 \rightarrow 0.40 \rightarrow 0.46)$. A thin zone of plagioclase occurs between the orthopyroxene-plagioclase symplectite and the garnet corona and it shows compositional zoning marked by the change from oligoclase $\left(\mathrm{An}_{25}\right)$ to labradorite $\left(\mathrm{An}_{68}\right)$ in the direction from symplectite to the garnet zone (Fig. 6d). Plagioclase in the whole sample is completely recrystallized into fine-grained clusters of crystals showing strong compositional zoning (Fig. 6d) characterized by the increasing anorthite content from core $\left(\mathrm{An}_{35-46}\right)$ to the rim $\left(\mathrm{An}_{79-94}\right.$; Fig. 3a, Tab. 3). Small grains of spinel, corundum, and kyanite occur within the recrystallized plagioclase. The crystals of plagioclase show a weak shapepreferred orientation defining the fabric and suggesting that the recrystallization was associated with deformation. The other primary minerals (orthopyroxene, clinopyroxene, and ilmenite) do not show such features nor were they observed in any of the other studied samples.

\section{P-T conditions}

Metamorphic conditions associated with formation of the corona textures have been constrained using the metamorphic assemblages in the selected samples. 
Only three samples were used for geobarometry, namely those bearing garnet-bearing coronas (PJ5 from TCC, PJ6 from MLC near the contact with TCC, and PJ9 from MLC). The reason is that they contain the plagioclase-amphibole-garnet-kyanite assemblage suitable for both multi-equilibrium and conventional geothermobarometry.

For the characterization of metamorphic $\mathrm{P}-\mathrm{T}$ conditions in the studied coronitic metagabbros (and coronitic rocks in general), the primary (magmatic) mineral assemblage is considered as metastable with respect to corona formation and thus it has to be avoided in the calculations. Moreover, corona formation is typically associated with chemical potential gradients of the components present and therefore even the formation of two adjacent layers of corona sequence cannot be considered to represent a thermodynamic equilibrium. Considering this fact, the minerals used for $\mathrm{P}-\mathrm{T}$ calculations were carefully selected so that they come exclusively from the garnet corona and occur in a close proximity to each other. Thus the chemical composition of garnet in the vicinity of amphibole, plagioclase and kyanite inclusions was used in the calculations (Tab. 4).

\subsection{Multiequilibrium geothermobarometry}

For the purpose of the average $\mathrm{P}-\mathrm{T}$ calculations, activities of mineral end-members in phases considered for $\mathrm{P}-\mathrm{T}$ estimates were calculated using the AX software (accessible at http://www.esc.cam.ac.uk/research/researchgroups/research-projects/tim-hollands-software-pages/ $a x)$. Calculations were carried out equally for the mineral assemblage garnet-amphibole-plagioclase-kyanite in all the selected samples. First set of calculations, done with $\mathrm{H}_{2} \mathrm{O}$ in excess, gave the following $\mathrm{P}-\mathrm{T}$ conditions (Tab. 5, all errors are $2 \sigma$ ): sample PJ5 $-720 \pm 172{ }^{\circ} \mathrm{C}$ and $12.3 \pm 4.6 \mathrm{kbar}$; sample $\mathrm{PJ} 6-765 \pm 100^{\circ} \mathrm{C}$ and $14.5 \pm 2.8$ kbar; sample PJ9 $-815 \pm 112^{\circ} \mathrm{C}$ and $16.3 \pm 3.6$ kbar.

However, the $a \mathrm{H}_{2} \mathrm{O}$ values are expected to be generally low in the coronitic rocks; e.g., St-Onge and Ijewliw (1996) estimated water activities in similar coronitic metagabbros from Canada to values as low as $0.3-0.1$. Indeed, the observed textures, represented by coronas and symplectites, indicate that the studied metamorphism occurred under $\mathrm{H}_{2} \mathrm{O}$-undersaturated conditions. In order to deal with this problem, calculations with $\mathrm{H}_{2} \mathrm{O}$-absent equilibria were attempted, giving the following results (Tab. 5): sample PJ5 $-556 \pm 158^{\circ} \mathrm{C}$ and $9.1 \pm 3.4$ kbar; sample PJ6 $-679 \pm 244^{\circ} \mathrm{C}$ and $12.7 \pm 5.4$ kbar; sample PJ9 $-607 \pm 100^{\circ} \mathrm{C}$ and $11.7 \pm 4.6$ kbar. Thus these $\mathrm{H}_{2} \mathrm{O}$-absent calculations led to lower mean P-T estimates, especially for samples PJ5 and PJ9, while the conditions calculated for sample PJ6 did not change significantly.
It is clear that for our studied samples the assumed $a \mathrm{H}_{2} \mathrm{O}$ has large effect on the average $\mathrm{P}-\mathrm{T}$ calculation results. This means that at least an approximate estimate of the $a \mathrm{H}_{2} \mathrm{O}$ values is needed in order to obtain reasonably precise $\mathrm{P}-\mathrm{T}$ results. Following the approach of Pitra et al. (2010), a series of average P-T calculations with identical mineral assemblage and varying $a \mathrm{H}_{2} \mathrm{O}$ was performed. Examining the dependence of calculation errors and the results of the $\chi^{2}$ test ("fit" value) on $a \mathrm{H}_{2} \mathrm{O}$, one can estimate the correct values of $a \mathrm{H}_{2} \mathrm{O}$. The summary of the average $\mathrm{P}-\mathrm{T}$ calculations with $a \mathrm{H}_{2} \mathrm{O}$ values ranging from 0 to 1 is given in Tab. 6. The lowest uncertainties and the best "fit" values are obtained for very low $a \mathrm{H}_{2} \mathrm{O}$ $(\sim 0.1)$ in samples PJ5 and PJ9. The sample PJ6 are also gives the lowest uncertainties for the $a \mathrm{H}_{2} \mathrm{O}=0.1$, however both uncertainties and the "fit" value do not change significantly with increasing $a \mathrm{H}_{2} \mathrm{O}$.

It is important to note that in all cases, the results of average $\mathrm{P}-\mathrm{T}$ calculations passed the statistical test for the entire range of $a \mathrm{H}_{2} \mathrm{O}$, which means that it is not possible to estimate the $a \mathrm{H}_{2} \mathrm{O}$ precisely. However, based on the optimal parameters (uncertainties and the "fit" value), it can be assumed that water activity in the studied rocks was generally rather low. Thus the $a \mathrm{H}_{2} \mathrm{O}$ for the final average $\mathrm{P}-\mathrm{T}$ calculations was set between 0.1 and 0.3 . Using the plagioclase-amphibole-garnetkyanite assemblage, the following range of temperatures and pressures was calculated for the selected samples $\left(a \mathrm{H}_{2} \mathrm{O}=0.1 \rightarrow 0.3\right.$, uncertainties given as $2 \sigma ;$ Fig. 8): PJ5:

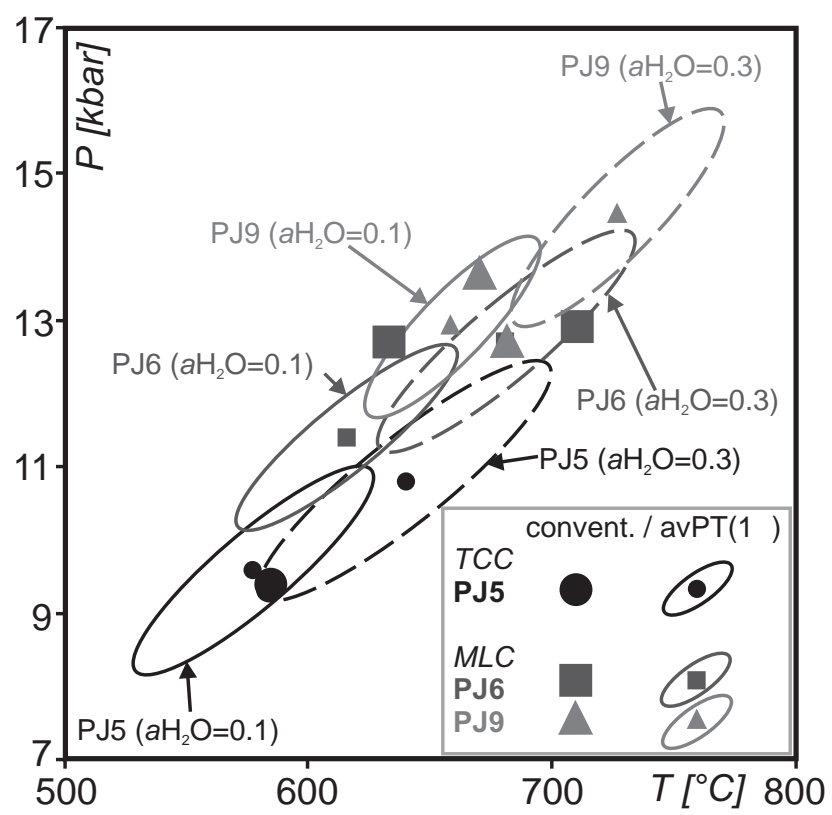

Fig. $8 \mathrm{P}-\mathrm{T}$ diagram showing correlation of the results obtained using conventional and multiequilibrium (average $\mathrm{P}-\mathrm{T}$ calculations) geothermobarometry. The results of the average $\mathrm{P}-\mathrm{T}$ calculations are plotted with $1 \sigma$ uncertainties and were calculated assuming $a \mathrm{H}_{2} \mathrm{O}$ of 0.1 (solidline ellipse) and 0.3 (dashed ellipse). 
Tab. 5 Results of multi-equilibrium thermobarometry calculations using average P-T calculations in THERMOCALC. Conditions were estimated for the samples PJ5, PJ6 and PJ9 for $\mathrm{H}_{2} \mathrm{O}$-absent $\left(a \mathrm{H}_{2} \mathrm{O}=0\right)$ and $\mathrm{H}_{2} \mathrm{O}$ present $\left(a \mathrm{H}_{2} \mathrm{O}=0.1-1\right)$ conditions

\begin{tabular}{|c|c|c|c|c|c|c|c|c|c|c|}
\hline \multicolumn{11}{|c|}{ Sample PJ5 } \\
\hline \multirow{2}{*}{$\begin{array}{l}\text { Phase: } \\
\text { Endmember: }\end{array}$} & \multicolumn{4}{|c|}{ Amphibole } & \multicolumn{2}{|c|}{ Plagioclase } & \multicolumn{3}{|c|}{ Garnet } & \multirow{2}{*}{$\begin{array}{c}\text { Kyanite } \\
\text { ky }\end{array}$} \\
\hline & $\operatorname{tr}$ & fact & ts & parg & an & $\mathrm{ab}$ & py & gr & alm & \\
\hline Activity & 0.240 & 0.000 & 0.004 & 0.018 & 0.710 & 0.570 & 0.017 & 0.017 & 0.150 & 1.000 \\
\hline $\operatorname{sd}(a) / a$ & 0.156 & 0.996 & 0.700 & 0.482 & 0.050 & 0.055 & 0.498 & 0.497 & 0.198 & \\
\hline \multicolumn{5}{|l|}{$a \mathrm{H}_{2} \mathrm{O}=1.0$} & \multicolumn{5}{|c|}{$\mathrm{H}_{2} \mathrm{O}$ absent } & \\
\hline \multicolumn{5}{|c|}{ excluded endmember: spessartine } & \multicolumn{5}{|c|}{ excluded endmember: spessartine } & \\
\hline \multicolumn{5}{|c|}{ Independent set of reactions } & \multicolumn{5}{|c|}{ Independent set of reactions } & \\
\hline \multicolumn{5}{|c|}{ 1) $3 \mathrm{tr}+8 \mathrm{gr}+24 \mathrm{ky}=3 \mathrm{ts}+24 \mathrm{an}+2 \mathrm{py}$} & \multicolumn{6}{|c|}{ 1) $3 \mathrm{tr}+8 \mathrm{gr}+24 \mathrm{ky}=3 \mathrm{ts}+24 \mathrm{an}+2 \mathrm{py}$} \\
\hline \multicolumn{5}{|c|}{ 2) $5 \mathrm{ts}+20 \mathrm{an}=3 \mathrm{tr}+8 \mathrm{gr}+22 \mathrm{ky}+2 \mathrm{H}_{2} \mathrm{O}$} & \multicolumn{6}{|c|}{ 2) $9 \mathrm{tr}+6 \mathrm{fact}+40 \mathrm{gr}+120 \mathrm{ky}=15 \mathrm{ts}+120 \mathrm{an}+10 \mathrm{alm}$} \\
\hline \multicolumn{5}{|c|}{ 3) $3 \mathrm{fact}+8 \mathrm{gr}+27 \mathrm{ky}=30 \mathrm{an}+5 \mathrm{alm}+3 \mathrm{H}_{2} \mathrm{O}$} & \multicolumn{6}{|c|}{ 3) 9 ts $+6 a b+4 p y+8 g r=3 \operatorname{tr}+6 p a r g+24 a n$} \\
\hline \multicolumn{5}{|c|}{ 4) $9 \mathrm{ts}+6 \mathrm{ab}+4 \mathrm{py}+8 \mathrm{gr}=3 \mathrm{tr}+6 \mathrm{parg}+24 \mathrm{an}$} & & & & & & \\
\hline
\end{tabular}

For $95 \%$ confidence, fit $<1.73$

For $95 \%$ confidence, fit $<1.96$

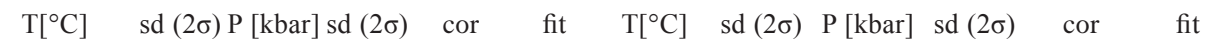

\begin{tabular}{|c|c|c|c|c|c|c|c|c|c|c|}
\hline 720 & 172 & 12.3 & 4.6 & 0.893 & 1.61 & 556 & 158 & 9.1 & 3.4 & 0.943 \\
\hline \multicolumn{11}{|c|}{ Sample PJ6 } \\
\hline Phase: & \multicolumn{4}{|c|}{ Amphibole } & \multicolumn{2}{|c|}{ Plagioclase } & \multicolumn{3}{|c|}{ Garnet } & Kyanite \\
\hline Endmember: & tr & fact & ts & parg & an & $\mathrm{ab}$ & py & gr & alm & ky \\
\hline Activity & 0.091 & 0.000 & 0.001 & 0.056 & 0.590 & 0.650 & 0.029 & 0.036 & 0.100 & 1.000 \\
\hline $\operatorname{sd}(a) / a$ & 0.293 & 1.119 & 3.900 & 0.316 & 0.050 & 0.050 & 0.432 & 0.404 & 0.258 & \\
\hline
\end{tabular}

$a \mathrm{H}_{2} \mathrm{O}=1.0$

excluded endmember: spessartine

$\mathrm{H}_{2} \mathrm{O}$ absent

Independent set of reactions

excluded endmember: spessartine

Independent set of reactions

1) $3 \mathrm{tr}+8 \mathrm{gr}+24 \mathrm{ky}=3 \mathrm{ts}+24 \mathrm{an}+2 \mathrm{py}$

1) $3 \mathrm{tr}+8 \mathrm{gr}+24 \mathrm{ky}=3 \mathrm{ts}+24 \mathrm{an}+2 \mathrm{py}$

2) $3 \mathrm{tr}+8 \mathrm{gr}+27 \mathrm{ky}=30 \mathrm{an}+5 \mathrm{py}+3 \mathrm{H}_{2} \mathrm{O}$

2) $3 \mathrm{fact}+5 \mathrm{py}=3 \mathrm{tr}+5 \mathrm{alm}$

3) $3 \mathrm{fact}+8 \mathrm{gr}+27 \mathrm{ky}=30 \mathrm{an}+5 \mathrm{alm}+3 \mathrm{H}_{2} \mathrm{O}$

3) $9 \mathrm{ts}+6 \mathrm{ab}+4 \mathrm{py}+8 \mathrm{gr}=3 \mathrm{tr}+6 \mathrm{parg}+24 \mathrm{an}$

4) $9 \mathrm{ts}+6 \mathrm{ab}+4 \mathrm{py}+8 \mathrm{gr}=3 \mathrm{tr}+6 \mathrm{parg}+24 \mathrm{an}$

For $95 \%$ confidence, fit $<1.73$

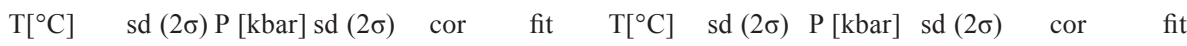

\begin{tabular}{llllllllllll}
765 & 50 & 14.5 & 1.4 & 0.901 & 0.65 & 679 & 122 & 12.7 & 2.7 & 0.978 & 0.6 \\
\hline
\end{tabular}

\begin{tabular}{|c|c|c|c|c|c|c|c|c|c|c|}
\hline \multicolumn{11}{|c|}{ Sample PJ9 } \\
\hline Phase: & \multicolumn{4}{|c|}{ Amphibole } & \multicolumn{2}{|c|}{ Plagioclase } & \multicolumn{3}{|c|}{ Garnet } & Kyanite \\
\hline Endmember: & $\operatorname{tr}$ & fact & ts & parg & an & $a b$ & py & gr & alm & ky \\
\hline Activity & 0.558 & 0.000 & 0.002 & 0.067 & 0.530 & 0.670 & 0.085 & 0.034 & 0.057 & 1.000 \\
\hline $\operatorname{sd}(\mathrm{a}) / \mathrm{a}$ & 0.125 & 1.216 & 1.700 & 0.290 & 0.066 & 0.050 & 0.283 & 0.411 & 0.341 & 0.000 \\
\hline
\end{tabular}

$a \mathrm{H}_{2} \mathrm{O}=1.0$

excluded endmember: spessartine

Independent set of reactions

1) $3 \mathrm{tr}+8 \mathrm{gr}+24 \mathrm{ky}=3 \mathrm{ts}+24 \mathrm{an}+2 \mathrm{py}$

2) $5 \mathrm{ts}+20 \mathrm{an}=3 \mathrm{tr}+8 \mathrm{gr}+22 \mathrm{ky}+2 \mathrm{H}_{2} \mathrm{O}$

3) $3 \mathrm{fact}+8 \mathrm{gr}+27 \mathrm{ky}=30 \mathrm{an}+5 \mathrm{alm}+3 \mathrm{H}_{2} \mathrm{O}$

4) $9 \mathrm{ts}+6 \mathrm{ab}+4 \mathrm{py}+8 \mathrm{gr}=3 \mathrm{tr}+6 \mathrm{parg}+24 \mathrm{an}$

$\mathrm{H}_{2} \mathrm{O}$ absent

excluded endmember: spessartine

Independent set of reactions

1) $3 \mathrm{tr}+8 \mathrm{gr}+24 \mathrm{ky}=3 \mathrm{ts}+24 \mathrm{an}+2 \mathrm{py}$

2) $3 \mathrm{tr}+5 \mathrm{alm}=3 \mathrm{fact}+5 \mathrm{py}$

3) $9 \mathrm{ts}+6 \mathrm{ab}+4 \mathrm{py}+8 \mathrm{gr}=3 \mathrm{tr}+6 \mathrm{parg}+24 \mathrm{an}$

For $95 \%$ confidence, fit $<1.73$

For $95 \%$ confidence, fit $<1.96$

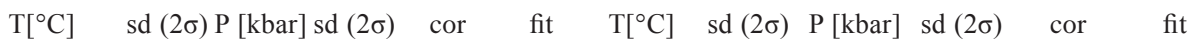

$$
\begin{array}{llllllllllll}
815 & 56 & 16.3 & 1.8 & 0.873 & 1.42 & 607 & 100 & 11.7 & 2.3 & 0.972 & 0.96
\end{array}
$$

$a \mathrm{H}_{2} \mathrm{O}$ - water activity; cor - correlation coefficient; fit - result of the $\chi^{2}$ test

end member abbreviations: $\mathrm{tr}$ - tremolite; fact - Fe-actinolite; ts - tschermackite; parg - pargasite

an - anortite; ab - albite; py - pyrope; gr - grossular; alm - almandine; ky - kyanite
$\mathrm{T}=578 \pm 78 \rightarrow 640 \pm 96^{\circ} \mathrm{C}$ $\mathrm{P}=9.6 \pm 2.2 \rightarrow 10.8 \pm 2.6$ $\mathrm{kb}$ a r, $\mathrm{P} \mathrm{J} 6: \mathrm{T}=$ $616 \pm 72 \rightarrow 681 \pm 84{ }^{\circ} \mathrm{C}$, $\mathrm{P}=11.4 \pm 2.0 \rightarrow 12.7 \pm 2.4$ $\mathrm{kb}$ a r a n d P J 9 : $\mathrm{T}=659 \pm 58 \rightarrow 727 \pm 70^{\circ} \mathrm{C}$, $\mathrm{P}=12.9 \pm 2.0 \rightarrow 14.4 \pm 2.4$ kbar.

\subsection{Conventional geothermobarometry}

Using the methods of conventional thermobarometry (Kohn and Spear 1990; Ravna 2000; Tab. 7; Fig. 8), the results for the sample PJ5 from the TCC indicate $\mathrm{P}-\mathrm{T}$ conditions of $585^{\circ} \mathrm{C}$ and 9.4 kbar. Two sets of analyses from the MLC sample PJ6 yielded higher metamorphic conditions of $634^{\circ} \mathrm{C}$ at $12.7 \mathrm{kbar}$ and $711^{\circ} \mathrm{C}$ at 12.9 kbar, respectively. Similarly, the sample PJ9 from the MLC gave $671^{\circ} \mathrm{C}$ at $13.6 \mathrm{kbar}$ and $681^{\circ} \mathrm{C}$ at 12.7 kbar. Although the methods of conventional geothermobarometry do not allow determining uncertainties, which can be generally very large (e.g. Powell and Holland 2008), the comparison of the results with those obtained by the multiequilibrium geothermobarometry shows a generally good match of both approaches.

Considering the estimated $\mathrm{P}-\mathrm{T}$ conditions, it is demonstrated that the corona formation-related metamorphism near the boundary between TCC and MLC reached the upper amphibolite- 
facies conditions. The lowest $\mathrm{P}-\mathrm{T}$ conditions were estimated for sample PJ5 from the TCC (Fig. 8). Taking into account the spatial distribution of the selected samples, the calculated $\mathrm{P}-\mathrm{T}$ conditions imply a rather continuous increase in metamorphic grade towards the structural footwall, i.e. from the east-southeast to the westnorthwest.

\section{Whole-rock geochemistry}

Based on the C.I.P.W. norm, all analysed samples are hypersthene-normative and, except for the sample PJ7 from the TCC-MLC boundary containing below $1 \%$ of normative quartz, also olivine-normative. The normative plagioclase corresponds to labradorite $\left(\mathrm{An}_{52-57}\right)$. Sample PJ7 is a gabbro-norite, while all the other samples correspond to olivine gabbro-norite. Samples PJ8 and VP46 are noticeably rich in normative olivine ( $\sim 25$ and $36 \%$ respectively) suggesting that they may represent cumulates.

Since all of the studied samples have undergone some degree of metamorphic changes, which may be connected with an influx or depletion of mobile elements with respect to magmatic protolith, diagrams used here for the classification and characterization of the samples are primarily based on immobile element contents. The TAS proxy diagram $\mathrm{Nb} / \mathrm{Y}$ vs. $\mathrm{Zr} /$ Ti (Fig. 9a; Pearce 1996, after Floyd and Winchester 1975) shows that the studied samples correspond to subalkali basalts/basaltic andesites except for the olivine-bearing sample VP46, which falls into the alkali basalt field. Similar signatures can be deduced from the ternary plot relating the cation percentages of $\mathrm{Al}_{2} \mathrm{O}_{3}, \mathrm{FeO}$ $+\mathrm{Fe}_{2} \mathrm{O}_{3}+\mathrm{TiO}_{2}$, and $\mathrm{MgO}$ (Fig 9b; Jensen 1976), where four of the studied samples correspond mostly to high-Mg tholeiitic basalts. Significant enrichment in $\mathrm{Mg}$ content
Tab. 6 Results of $\mathrm{P}-\mathrm{T}$ calculations using multi-equilibrium thermobarometry for range of $\mathrm{H}_{2} \mathrm{O}$ activi-

\begin{tabular}{|c|c|c|c|c|c|c|c|}
\hline Sample & $a \mathrm{H}_{2} \mathrm{O}$ & $\operatorname{avT}\left[{ }^{\circ} \mathrm{C}\right]$ & $\operatorname{sd}(2 \sigma)$ & avP [kbar] & $\operatorname{sd}(2 \sigma)$ & cor & fit \\
\hline \multirow[t]{9}{*}{ PJ5 } & \multicolumn{7}{|c|}{ For $95 \%$ confidence, fit $<1.96$} \\
\hline & 0 & 556 & 158 & 9.1 & 3.4 & 0.943 & 1.02 \\
\hline & \multicolumn{7}{|c|}{ For $95 \%$ confidence, fit $<1.73$} \\
\hline & 0.1 & 578 & 78 & 9.6 & 2.2 & 0.867 & 0.75 \\
\hline & 0.3 & 640 & 96 & 10.8 & 2.6 & 0.880 & 1.07 \\
\hline & 0.5 & 672 & 124 & 11.4 & 3.4 & 0.885 & 1.29 \\
\hline & 0.7 & 695 & 146 & 11.9 & 4.0 & 0.889 & 1.44 \\
\hline & 0.9 & 712 & 164 & 12.2 & 4.4 & 0.892 & 1.56 \\
\hline & 1.0 & 720 & 172 & 12.3 & 4.6 & 0.893 & 1.61 \\
\hline \multirow[t]{9}{*}{ PJ6 } & \multicolumn{7}{|c|}{ For 95\% confidence, fit $<1.96$} \\
\hline & 0 & 679 & 244 & 12.7 & 5.4 & 0.978 & 0.60 \\
\hline & \multicolumn{7}{|c|}{ For $95 \%$ confidence, fit $<1.73$} \\
\hline & 0.1 & 616 & 72 & 11.4 & 2.0 & 0.875 & 0.60 \\
\hline & 0.3 & 681 & 84 & 12.7 & 2.4 & 0.888 & 0.43 \\
\hline & 0.5 & 715 & 90 & 13.4 & 2.4 & 0.893 & 0.48 \\
\hline & 0.7 & 739 & 96 & 13.9 & 2.6 & 0.897 & 0.55 \\
\hline & 0.9 & 757 & 98 & 14.3 & 2.6 & 0.900 & 0.62 \\
\hline & 1.0 & 765 & 100 & 14.5 & 2.8 & 0.901 & 0.65 \\
\hline \multirow[t]{9}{*}{ PJ9 } & \multicolumn{7}{|c|}{ For 95\% confidence, fit $<1.96$} \\
\hline & 0 & 607 & 200 & 11.7 & 4.6 & 0.972 & 0.96 \\
\hline & \multicolumn{7}{|c|}{ For $95 \%$ confidence, fit $<1.73$} \\
\hline & 0.1 & 659 & 58 & 12.9 & 2.0 & 0.846 & 0.77 \\
\hline & 0.3 & 727 & 70 & 14.4 & 2.4 & 0.860 & 1.04 \\
\hline & 0.5 & 763 & 86 & 15.1 & 2.8 & 0.866 & 1.19 \\
\hline & 0.7 & 787 & 98 & 15.7 & 3.2 & 0.870 & 1.30 \\
\hline & 0.9 & 807 & 108 & 16.1 & 3.6 & 0.872 & 1.38 \\
\hline & 1.0 & 815 & 112 & 16.3 & 3.6 & 0.873 & 1.42 \\
\hline
\end{tabular}

$a \mathrm{H}_{2} \mathrm{O}$ - water activity; cor - correlation coefficient ; fit - result of the $\chi^{2}$ test

of the two olivine-bearing samples VP46 and PJ8 is then supporting the interpretation that they represent olivine cumulates.

Binary diagrams based on ratios of selected immobile elements $(\mathrm{Nb} / \mathrm{Yb}, \mathrm{Nb} / \mathrm{Th}$ and Ti/Yb, Figs $9 \mathrm{c}-\mathrm{d}$, after Pearce 2008) were used in order to define magma types corresponding to the studied gabbro samples and subsequently to assess their likely tectonic setting. In the $\mathrm{Nb} / \mathrm{Yb}$ vs. $\mathrm{Th} / \mathrm{Yb}$ plot (Fig. 9c) all the studied samples have signatures close to that of the E-MORB. Since all the samples show no significant increase in the $\mathrm{Th} / \mathrm{Nb}$ ratio above the 'Mantle Array' (NMORB-OIB line), it can be concluded that they

Tab. 7 P-T conditions estimated using conventional geothermobarometry

\begin{tabular}{lcccc}
\hline sample & $\mathrm{T}\left({ }^{\circ} \mathrm{C}\right)$ & $\begin{array}{c}\text { geothermometer of } \\
\text { Ravna }(2000)\end{array}$ & $\mathrm{P}(\mathrm{kbar})$ & $\begin{array}{c}\text { geobarometer of Kohn } \\
\text { and Spear (1990) }\end{array}$ \\
\hline PJ5 & 585 & Grt-Hbl & 9.4 & Grt-Hbl-Pl \\
PJ6 & 634 & Grt-Hbl & 12.7 & Grt-Hbl-Pl \\
& 711 & Grt-Hbl & 12.9 & Grt-Hbl-Pl \\
PJ9 & 671 & Grt-Hbl & 13.6 & Grt-Hbl-Pl \\
& 681 & Grt-Hbl & 12.7 & Grt-Hbl-Pl \\
\hline
\end{tabular}



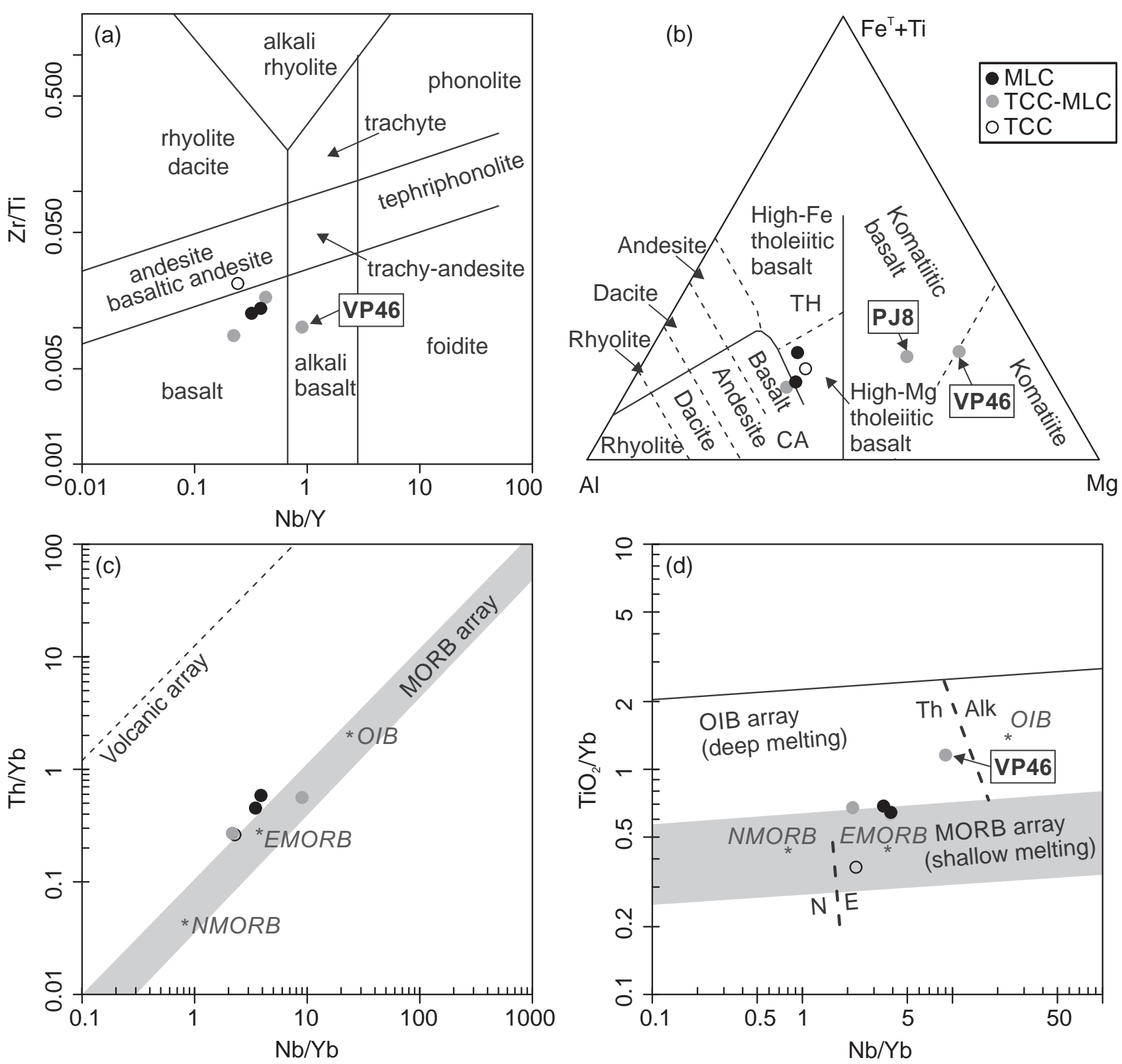

Fig. 9 Classification and discriminant diagrams showing the character and tectonic setting of the studied gabbros. a - The immobile element-based TAS proxy diagram (Pearce 1996, after Floyd and Winchester 1975); b - Ternary plot relating the cation percentages of $\mathrm{Al}_{2} \mathrm{O}_{3}, \mathrm{FeO}+\mathrm{Fe}_{2} \mathrm{O}_{3}+\mathrm{TiO}_{2}$, and $\mathrm{MgO}$ (Jensen 1976); c - Binary diagram Nb/Yb vs. Th/Yb (Pearce 2008, 2014). The 'MORB-OIB array' is formed by average N-MORB, E-MORB and OIB compositions taken from Sun and McDonough (1989). The Th/ Nb proxy is used to distinguish suprasubduction zone from midocean ridge basalts; $\mathbf{d}-\mathrm{The} \mathrm{Nb} / \mathrm{Yb}-\mathrm{TiO}_{2} / \mathrm{Yb}$ diagram to discriminate between the deep and shallow melting leading to formation of $\mathrm{N}-\mathrm{MORB}$, E-MORB, and OIB (Pearce 2008, 2014).

were generally neither affected by subduction-derived fluid/melt nor significantly contaminated by a mature crustal material. The Ti/Yb ratios of the samples (Fig. 9d) are low, typical of shallow (spinel) mantle melting and correspond to E-MORB, except the olivine cumulate VP46.

The E-MORB character of the studied gabbros is also supported by multielement plots (Fig. 10). Contents of presumably immobile trace elements normalized to N-MORB (Fig. 10a, after Pearce 2014) resemble typical E-MORB (Sun and McDonough 1989) except again for the olivine cumulate VP46 that is depleted in all of the elements compared to the other samples. Similarly in the REE spider plots normalized to chondrite composition (Fig. 10b, after Boynton 1984), the patterns correspond to the E-MORB. Positive Eu-anomaly in the sample PJ7 indicates a role of plagioclase accumulation during its formation. 


\section{Discussion}

\subsection{Geochemical characteristics of the studied metagabbro in the context of previous studies}

The geochemical characteristics of the studied metagabbros from the TCC-MLC boundary show that their composition generally corresponds to tholeiitic basalts, which is in agreement with previous studies (Beard et al. 1995; Štědrá et al. 2002; Timmermann et al. 2004). Their relatively immobile trace-element signatures display a clear affinity to E-MORB with no significant contribution of subduction-derived fluid/melt or continental crust material and with composition typical of shallow mantle melting. Such signatures indicate that the formation of the gabbros was not connected to a subduction-related environment but it was rather associated to rifting of the crust. This is in agreement with interpretations that the gabbros were intruded into an already established crustal stack involving the metasedimentary TCC and eclogitebearing MLC as proposed by Štědrá et al. (2002). This intrusion may have been then related to a formation of a rift in the Teplá-Barrandian Unit that was presumably triggered by the onset of the Iapetus Ocean subduction at $\sim 510 \mathrm{Ma}$ as proposed by Žák et al. (2013).

\subsection{Metamorphic characteristics of the studied metagabbros in the context of previous studies}

The contact of the TCC and MLC represents an important lithological and tectonic boundary in the northwestern Bohemian Massif. However, the character and significance of this boundary remains unclear since the two neighboring but mechanically contrasting complexes have undergone polyphase and rather complicated history over a wide time span from $\sim 550$ to $\sim 370 \mathrm{Ma}$. On the other hand, the studied metagabbros occurring in both complexes show formation of comparable static corona textures associated with a single metamorphic event and implying the absence of deformation overprint. Therefore the corona formation in these rocks represents an important process that allows linking and correlating at least part of the tectono-metamorphic history across the boundary between TCC and MLC.

Metamorphic conditions calculated for the sample PJ5 from the TCC indicate $578-640{ }^{\circ} \mathrm{C}$ and $9.1-10.8$ kbar. This corresponds well to the P-T conditions estimated for the surrounding metapelites in kyanite-zone at $550-645^{\circ} \mathrm{C}$ and $5-9 \mathrm{kbar}$ (Cháb a Žáček 1994). The higher $\mathrm{P}-\mathrm{T}$ conditions were calculated for the two MLC metagabbros $\left(616-715^{\circ} \mathrm{C}\right.$ at $11.4-12.9$ kbar for PJ6 and $659-727^{\circ} \mathrm{C}$ at $12.7-14.4 \mathrm{kbar}$ for PJ9). These estimates are in a good agreement with the previous data on the metamorphic overprint of the MLC gabbros $\left(600-730^{\circ} \mathrm{C}\right.$, 8-11 kbar: Štědrá $2001 ; 585-614^{\circ} \mathrm{C}, 12-13$ kbar: Faryad 2012).

In conclusion, the $\mathrm{P}-\mathrm{T}$ conditions calculated for the studied metagabbro samples correspond well to the peak metamorphic conditions and metamorphic field gradient recognized in the surrounding rocks, indicating an increase in $\mathrm{P}-\mathrm{T}$ conditions towards the northwest (Cháb and Žáček 1994; Žáček 1994; Cháb et al. 1997; Zulauf
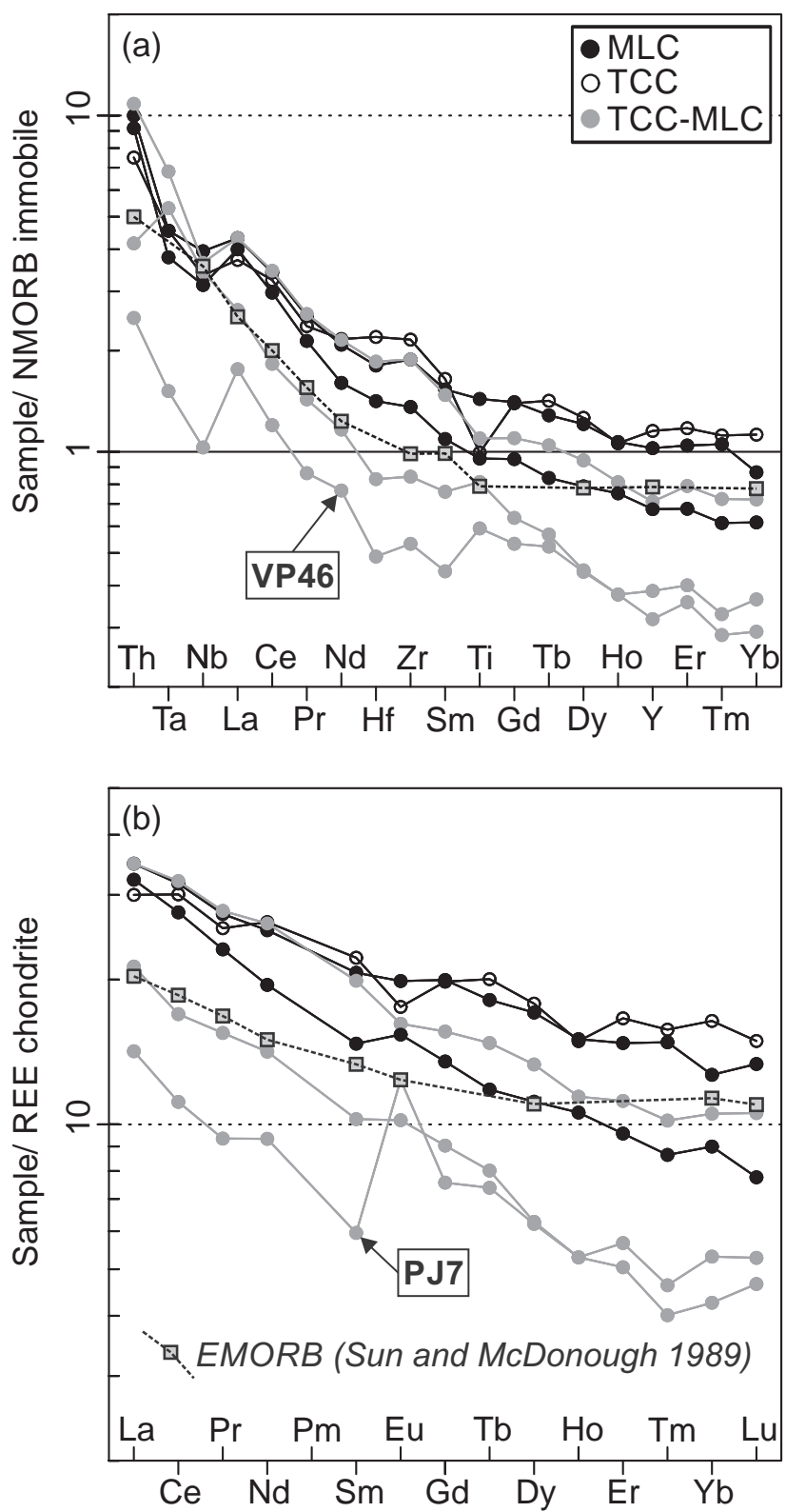

Fig. 10 Spider plots showing trace-element signatures in the studied samples; average E-MORB composition (Sun and McDonough 1989) is plotted for comparison. a - Relatively immobile trace elements normalized to N-MORB (after Pearce 2014, normalizing values from Sun and McDonough 1989), b - REE normalized by average chondrite composition (Boynton 1984). 
Tab. 8 Whole-rock chemical compositions of studied metagabbros

\begin{tabular}{|c|c|c|c|c|c|c|}
\hline \multicolumn{7}{|c|}{ major elements (oxides in wt. \%) } \\
\hline sample & PJ5 & PJ6 & PJ7 & PJ8 & PJ9 & VP46 \\
\hline $\mathrm{SiO}_{2}$ & 49.06 & 47.93 & 51.34 & 45.86 & 47.92 & 43.67 \\
\hline $\mathrm{TiO}_{2}$ & 1.26 & 1.82 & 0.75 & 1.39 & 1.21 & 1.03 \\
\hline $\mathrm{Al}_{2} \mathrm{O}_{3}$ & 15.62 & 16.51 & 17.14 & 11.17 & 17.97 & 7.01 \\
\hline $\mathrm{Fe}_{2} \mathrm{O}_{3}$ & 9.40 & 11.52 & 7.55 & 14.31 & 8.57 & 16.62 \\
\hline $\mathrm{Cr}_{2} \mathrm{O}_{3}$ & 0.077 & 0.021 & 0.030 & 0.156 & 0.049 & 0.171 \\
\hline $\mathrm{MnO}$ & 0.17 & 0.19 & 0.17 & 0.20 & 0.14 & 0.19 \\
\hline $\mathrm{MgO}$ & 8.49 & 8.08 & 7.88 & 17.30 & 8.99 & 22.08 \\
\hline $\mathrm{CaO}$ & 11.61 & 10.01 & 10.71 & 6.39 & 10.52 & 5.28 \\
\hline $\mathrm{Na}_{2} \mathrm{O}$ & 2.80 & 2.83 & 2.84 & 1.92 & 2.87 & 1.26 \\
\hline $\mathrm{K}_{2} \mathrm{O}$ & 0.23 & 0.52 & 0.21 & 0.53 & 0.47 & 0.39 \\
\hline $\mathrm{P}_{2} \mathrm{O}_{5}$ & 0.15 & 0.19 & 0.07 & 0.20 & 0.15 & 0.12 \\
\hline total & 98.87 & 99.62 & 98.69 & 99.43 & 98.86 & 97.82 \\
\hline \multicolumn{7}{|c|}{ trace elements $(\mathrm{ppm})$} \\
\hline $\mathrm{Ba}$ & 1 & 158 & 68 & 135 & 121 & 54 \\
\hline Co & 38.1 & 41.9 & 37.0 & 84.4 & 40.8 & 119.6 \\
\hline Cs & 2.3 & 1.2 & 0.7 & 1.2 & 0.8 & 1.1 \\
\hline $\mathrm{Ga}$ & 15.7 & 17.9 & 16.4 & 13.4 & 15.3 & 10.5 \\
\hline Hf & 4.5 & 3.7 & 1.0 & 3.8 & 2.9 & 1.7 \\
\hline $\mathrm{Nb}$ & 7.8 & 9.2 & 2.4 & 8.5 & 7.3 & 8.0 \\
\hline $\mathrm{Rb}$ & 4.8 & 12.4 & 4.5 & 13.0 & 9.8 & 5.2 \\
\hline $\mathrm{Sr}$ & 192.2 & 242.5 & 264.6 & 177.8 & 305.5 & 166.2 \\
\hline $\mathrm{Ta}$ & 0.6 & 0.6 & 0.2 & 0.9 & 0.5 & 0.7 \\
\hline $\mathrm{Th}$ & 0.9 & 1.2 & 0.3 & 1.3 & 1.1 & 0.5 \\
\hline $\mathrm{U}$ & 0.2 & 0.4 & 0.1 & 0.7 & 0.5 & 0.1 \\
\hline V & 243 & 246 & 265 & 161 & 177 & 152 \\
\hline $\mathrm{Zr}$ & 159.5 & 139.2 & 39.4 & 139.3 & 100.6 & 62.4 \\
\hline $\mathrm{Y}$ & 32.3 & 28.7 & 10.8 & 19.9 & 18.9 & 8.9 \\
\hline $\mathrm{La}$ & 9.3 & 10.8 & 4.4 & 10.8 & 10.0 & 6.6 \\
\hline $\mathrm{Ce}$ & 24.3 & 25.6 & 9.0 & 25.9 & 22.3 & 13.7 \\
\hline $\operatorname{Pr}$ & 3.12 & 3.34 & 1.14 & 3.39 & 2.82 & 1.89 \\
\hline $\mathrm{Nd}$ & 15.8 & 15.2 & 5.6 & 15.7 & 11.7 & 8.5 \\
\hline $\mathrm{Sm}$ & 4.33 & 4.03 & 1.16 & 3.88 & 2.87 & 2.00 \\
\hline $\mathrm{Eu}$ & 1.29 & 1.46 & 0.91 & 1.19 & 1.13 & 0.75 \\
\hline Gd & 5.13 & 5.17 & 1.96 & 4.04 & 3.50 & 2.34 \\
\hline $\mathrm{Tb}$ & 0.95 & 0.86 & 0.35 & 0.70 & 0.56 & 0.38 \\
\hline Dy & 5.74 & 5.50 & 2.00 & 4.29 & 3.59 & 2.02 \\
\hline Ho & 1.07 & 1.08 & 0.38 & 0.82 & 0.76 & 0.38 \\
\hline Er & 3.49 & 3.10 & 1.19 & 2.35 & 2.01 & 1.06 \\
\hline $\mathrm{Tm}$ & 0.51 & 0.48 & 0.15 & 0.33 & 0.28 & 0.13 \\
\hline $\mathrm{Yb}$ & 3.43 & 2.65 & 1.11 & 2.20 & 1.88 & 0.89 \\
\hline $\mathrm{Lu}$ & 0.48 & 0.43 & 0.17 & 0.34 & 0.25 & 0.15 \\
\hline Mo & 0.5 & 0.6 & $<0.1$ & 0.8 & 0.4 & 0.8 \\
\hline $\mathrm{Cu}$ & 69.0 & 24.1 & 20.6 & 128.0 & 33.0 & 120.8 \\
\hline $\mathrm{Pb}$ & 0.5 & 1.0 & 0.5 & 1.0 & 1.9 & 1.0 \\
\hline $\mathrm{Zn}$ & 8 & 16 & 7 & 18 & 13 & 47 \\
\hline $\mathrm{Ni}$ & 28.0 & 31.0 & 21.4 & 475.3 & 71.1 & 506.5 \\
\hline As & $<0.5$ & 1.0 & 0.6 & 2.5 & $<0.5$ & $<0.5$ \\
\hline $\mathrm{Au}$ & 3.6 & 1.2 & 0.7 & 2.9 & 0.6 & 0.6 \\
\hline
\end{tabular}

2001; Peřestý 2012). The peak P-T conditions obtained from the TCC metapelites have been recently ascribed to the early-Variscan horizontal east-west shortening and crustal thickening (Peřestý 2012). It is inferred that the corresponding $\mathrm{P}-\mathrm{T}$ conditions obtained from the studied metagabbro were very likely associated with the same deformation phase. The subsequent exhumation, manifested by an intense tectonometamorphic overprint of surrounding rocks (Peřestý 2012), is reflected only by a weak retrogression identified in the studied TCC metagabbro PJ5.

The above-described metamorphic field gradient documented from metagabbro samples and surrounding rocks shows rather continuous increase in $\mathrm{P}-\mathrm{T}$ conditions across the contact between TCC and MLC. Such a lack of obvious gap in the Variscan metamorphic conditions supports the interpretation that the thickening event recognized in the TCC rocks was also responsible for the metamorphism of the studied metagabbros. This conclusion, together with the fact that both complexes were intruded by the Late Cambrian gabbros of similar geochemical signature (496-503 Ma: Bowes and Aftalion 1991; Timmermann et al. 2004), strongly suggests that both major lithological complexes were brought together prior to the gabbro intrusion during the Late Cambrian rifting.

It is important to point out that the metagabbros within the eclogite-bearing MLC reveal maximum pressure of $\sim 14$ kbar, which is generally lower compared to estimates for the eclogites (16-28 kbar, Jelínek et al. 1997; Štědrá 2001; Faryad 2012). This led Štědrá et al. (2002) and Timmermann et al. (2004) to suggest that the eclogitefacies metamorphism in the MLC may have been preVariscan, presumably older than $\sim 500 \mathrm{Ma}$ as constrained by the age of the gabbro intrusions. On the other hand, this study revealed a pressure increase from $\sim 10 \mathrm{kbar}$ (sample PJ5) to $\sim 14$ kbar (sample PJ9) from the TCC to the eastern part of the MLC over a horizontal distance of $\sim 15 \mathrm{~km}$. It is therefore possible that the eclogitefacies conditions with pressures of $\sim 18-20$ kbar could have been achieved in the western part of the MLC in the continuity of the presumably Variscan metamorphic field gradient. This argumentation was used by Faryad (2012) to support the Variscan age of the eclogite-facies metamorphism in the MLC.

However, the presence of eclogites is not limited to the northwestern MLC and several such bodies crop out directly at the contact between MLC and TCC. These eclogite occurrences are located $\sim 5 \mathrm{~km}$ east of the metagabbro sample PJ6 that did not reach pressures exceeding $13 \mathrm{kbar}$. Thus the occurrence of eclogites in the close proximity to metagabbros violates the otherwise continuous metamorphic field gradient and bids for a polymetamorphic character of the mafic rocks in the MLC. This stands in sharp contrast to the single metamorphic event recorded in the metagabbro. Indeed, the eclogites are overprinted by amphibolite-facies metamorphic assemblage. 
Based on the above arguments, it seems possible that eclogites were first intruded by gabbro and only then retrogressed under the amphibolite-facies conditions during the Variscan event. Because of the Late Cambrian intrusive age of the gabbro this in turn implies a pre-Variscan age for at least some of the MLC eclogites.

\subsection{Interpretation of the metamorphic textures}

The characteristic feature of the studied samples is a large variability of corona sequences developed at the contacts between primary minerals of the $M_{1}$ assemblage, namely between plagioclase and the mafic phases, olivine, orthopyroxene, clinopyroxene, amphibole, biotite, and ilmenite. While the magmatic origin of the $M_{1}$ mineral assemblage is rather convincing, the origin of the $M_{2}$ mineral assemblage needs to be discussed, since there is no general agreement on the process of corona formation. In different studies, the studied coronas were explained to result from 1) progressive reactions during magmatic crystallization (e.g. Joesten 1986), 2) subsolidus reactions during slow cooling and post-magmatic evolution (e.g. Whitney and McLelland 1973), or 3) post-magmatic metamorphism of the gabbroic rocks (e.g. Spear and Markussen 1997).

Corona sequences similar to those described in this study were already reported from several localities. Haas et al. (2002) described coronas formed between olivine and plagioclase in a gabbro from Norway and concluded that these textures were formed during a multi-stage, late-magmatic process. A comparable corona sequence around olivine (orthopyroxene $\rightarrow$ amphibole $\rightarrow \pm$ clinopyroxene-spinel symplectite) has been also observed in a troctolitic gabbro from Argentina (Gallien et al. 2012) where it was interpreted as being formed in several stages during cooling of the gabbro intrusion at the transition to granulite.

On the other hand, similar coronas were studied in a gabbro-norite from the Baltic Shield by Larikova (2000) and their formation was interpreted as a result of a prograde metamorphism of the magmatic rocks. This author has concluded that all the layers of the observed corona sequences had grown simultaneously by the mechanism of diffusion metasomatism. Simultaneous growth of multi-layer coronas by the metasomatism between olivine/orthopyroxene and plagioclase was later simulated experimentally by Larikova and Zaraisky (2009).

The formation of coronitic textures in metagabbros from the MLC and TCC could reflect a prograde metamorphism (e.g. Štědrá et al. 2002; Timmermann et al. 2004), even though some of the phases present in the coronas, i.e. Ti-rich amphibole and orthopyroxene, were interpreted as late magmatic (e.g. Štědrá et al. 2002 and references therein). The coronas described in this work do not show a polyphase metamorphic overprint except for sample PJ5, where the growth of chlorite, albite, muscovite, and prehnite can be attributed to a later retrogression. The gabbro bodies intruded into relatively shallow depths as indicated by the occurrence of hornblende and pyroxene hornfelses in thermal aureoles around some of the gabbro bodies (Kachlík 1997; Štědrá et al. 2002). This contrasts with the relatively higher pressures estimated from coronas in the current study. At the same time, metamorphic $\mathrm{P}-\mathrm{T}$ conditions of the gabbros show very good correlation with the record of Variscan metamorphism in the surrounding rocks. Based on these arguments, it can be concluded that the observed coronas, consisting of the $\mathrm{M}_{2}$ metamorphic mineral assemblage, were formed by prograde metamorphism superimposed on the significantly older ( $\sim 500 \mathrm{Ma})$ magmatic mineral assemblage $M_{1}$ during the regional metamorphic event of Variscan age.

An interesting feature observed in all studied samples is the occurrence of tiny zircon rims developed around magmatic $M_{1}$ ilmenite. Since zircon appears in such specific microstructural position, it can provide a valuable age constraints for either metamorphic or magmatic age related to $\mathrm{M}_{2}$ or $\mathrm{M}_{1}$ assemblage, respectively. Similar zircons have been previously reported by several authors, however their genetic interpretations did diverge. The metamorphic origin of such zircons was explained either by a direct crystallization (Sláma et al. 2007) or by exsolution of baddeleyite from magmatic ilmenite and its subsequent transformation to zircon during granulitefacies conditions (Bingen et al. 2001). The magmatic origin of the zircons was proposed by Morriset and Scoates (2008), who observed zircons around ilmenites in unmetamorphosed anorthosites from Quebec. Austrheim et al. (2008) concluded that the zircon rim around ilmenite in amphibolites and gabbros could be of magmatic origin or developed during subsequent metasomatism.

It is worth noting that the mineral assemblage enveloping ilmenite in our studied samples changes with the metamorphic grade. In the sample from the TCC, characterized by the lowest $\mathrm{P}-\mathrm{T}$ conditions, zircon around ilmenite is associated with titanite (Fig. 2b). The intermediate $\mathrm{P}-\mathrm{T}$ conditions recorded by the MLC and TCC-MLC boundary samples show ilmenite being rimmed only by zircon while the highest $\mathrm{P}-\mathrm{T}$ conditions recorded in sample PJ9 show ilmenite partially replaced by rutile, which is surrounded by the zircon grains (Fig. 7d). Microstructural relations in the studied samples do not provide clear evidence for magmatic or metamorphic origin of the zircon rims. A simple fact that zircon occurs as rims around magmatic ilmenite in coronitic rocks may suggest that the zircon itself represents a corona formed 
during metamorphism. On the other hand, the zircon grains present around ilmenite that was partially replaced by rutile in sample PJ9 may imply that zircon rim was formed before the metamorphism.

Almost all of the studied samples show an extensive recrystallization of magmatic plagioclase associated with formation of a two-plagioclase mixture. Grove et al. (1983) interpreted this microstructure with coexisting oligoclase/andesine and bytownite in terms of plagioclase immiscibility characteristic of the temperature range of $\sim 400-575^{\circ} \mathrm{C}$, as earlier defined by Spear (1977). In the case of the studied metagabbro samples, this microstructure can be then interpreted as a result of the magmatic plagioclase breakdown during metamorphism at temperatures in which the original (magmatic) composition of $\sim \mathrm{An}_{50-70}$ becomes unstable.

In addition, plagioclase in the studied samples often contains numerous small inclusions or lamellae of Al-rich phases such as spinel and/or corundum. Similar phenomenon often referred to as "clouding" of plagioclase was previously described by Poldervaart and Gilkey (1953) or Goldsmith (1982). The presence of tiny second-phase crystals in plagioclase mixture was interpreted to result from a diffusion-controlled process. The samples studied in this work are characterized by growth of coronas that contain Ca-bearing phases such as amphibole and garnet at the contact of $\mathrm{Ca}$-free olivine and orthopyroxene with plagioclase. Formation of such coronas requires consumption of $\mathrm{Ca}$ (and $\mathrm{Al}$ ) from plagioclase. Therefore, the crystallization of spinel and corundum within plagioclase may be interpreted as an indication of the higher diffusivity of $\mathrm{Ca}$ compared to $\mathrm{Al}$ out from plagioclase accompanied by $\mathrm{Mg}$ and $\mathrm{Fe}$ diffusion into plagioclase during the corona formation.

In summary, the process of plagioclase transformation can be divided into three stages: 1) crystallization of spinel and corundum in plagioclase due to diffusion of $\mathrm{Ca}>\mathrm{Al}$ from plagioclase accompanied with $\mathrm{Mg}+$ Fe diffusion into plagioclase, 2) breakdown of magmatic plagioclase (labradorite) to andesine-oligoclase and anorthite-bytownite, and 3) recrystallization of the magmatic plagioclase into the fine-grained clusters of zoned plagioclase grains with $\mathrm{Ca}$ increasing towards their rims (e.g. PJ9). While the stages 1 and 2 clearly represented a static process, the final recrystallization stage 3 in sample PJ9 was connected with late deformation-metamorphic overprint.

Most of these features were never described from the metagabbros of the TCC or MLC. On the other hand, some previous works (Zulauf 1997; Štědrá et al. 2002) have reported the presence of kyanite and zoisite grains in the calcic domains of plagioclase that were not observed in the present study. The only exception is the kyanite appearing in the plagioclase domains of the
MLC sample PJ9 that yields the highest metamorphic conditions. While it is difficult to link our observations with those reported by other authors, it is possible that the textures seen in our samples represent an initial stage of plagioclase decomposition, which was followed by complete recrystallization connected by formation of zoisite and kyanite during continuing metamorphism and deformation.

\section{Conclusions}

Petrological and geochemical investigations of the metamorphosed gabbros occurring at the contact of the Teplá-Barrandian Unit (TBU) and the Mariánské Lázně Complex (MLC) brought some constraints on the evolution of this important tectonic boundary. The $\mathrm{M}_{2}$ mineral assemblage associated with coronas formed around the primary magmatic $\mathrm{M}_{1}$ minerals as a result of static metamorphic overprint of the gabbro. The closely related minerals in the garnet-bearing coronas were used to estimate metamorphic $\mathrm{P}-\mathrm{T}$ conditions in several samples across the boundary of the Teplá Crystalline and Mariánské Lázně complexes (TCC and MLC, respectively). The lowest metamorphic conditions of $\sim 600 \pm 50^{\circ} \mathrm{C}$ and $10 \pm 1.5 \mathrm{kbar}$ were estimated from the TCC and the highest of $\sim 700 \pm 50^{\circ} \mathrm{C}$ and $13.5 \pm 1.5 \mathrm{kbar}$ were obtained from the MLC. The spatial arrangement of our P-T estimates suggests rather continuous increase in metamorphic grade from TCC to MLC, i.e. towards the west-northwest. The observed higher grade metamorphic field gradient across the TCC-MLC boundary corresponds well to the lower grade metamorphic field gradient recorded in the TCC where the peak metamorphic conditions have been associated with crustal thickening during Variscan event. It appears likely that the thickening was also responsible for the metamorphism of the metagabbro in the MLC thus questioning the Variscan age of the nearby eclogites. The whole-rock geochemical analyses show that metagabbros occurring in the TBU have compositions corresponding to tholeiitic basalts with trace-element signatures characteristic of E-MORB, which is consistent with interpretation that the intrusion of these rocks was related to an intracontinental rifting of the TBU during late Cambrian and was not connected to any subduction processes.

Acknowledgements. V. Peřestý and O. Lexa are thanked for their help with sampling and numerous valuable discussions in the field and beyond. We gratefully acknowledge thorough reviews by P. Pitra and V. Štědrá and editorial handling by P. Hasalová. The work was financially supported by the Czech National Grant Agency (13-16315S to P. Štípská and O. Lexa). 


\section{References}

Austrheim H, Putnis CHV, Engvik AK, Putnis A (2008) Zircon coronas around Fe-Ti oxides: a physical reference frame for metamorphic and metasomatic reactions. Contrib Mineral Petrol 156: 517-527

Beard BL, Medaris LG, Johnson CM, Jelínek E, Tonika J, RiciPUTI LR (1995) Geochronology and geochemistry of eclogites from the Mariánské Lázně Complex, Czech Republic: implications for Variscan orogenesis. Geol Rundsch 84: 552-567

Bingen B, Austrheim H, Whitehouse M (2001) Ilmenite as a source for zirconium during high-grade metamorphism? Textural evidence from Caledonides of Western Norway and implications for zircon geochronology. J Petrol 42: 355-375

Bowes DR, Aftalion M (1991) U-Pb zircon isotopic evidence for early Ordovician and late Proterozoic units in the Mariánské Lázně Complex, Central European Hercynides. Neu Jb Mineral, Mh 7: 315-326

Bowes DR, van Breemen O, Hopgood AM, Jelínek E (2002) ${ }^{40} \mathrm{Ar} /{ }^{39} \mathrm{Ar}$ isotopic evidence for mid-Devonian postmetamorphic pegmatite emplacement in the Mariánské Lázně Complex, Bohemian Massif, Central European Hercynides. Neu Jb Miner, Mh 10: 445-457

Boynton WV (1984) Cosmochemistry of the rare earth elements: meteorite studies. In: HENDERSON P (ed) Rare Earth Element Geochemistry. Elsevier, Amsterdam, pp 63-114 СнÁB J, ŽÁČ́K V (1994) Metamorphism of the Teplá Crystalline Complex. KTB Report 94-3, Niedersächsischen Landesamt für Bodenforschung, Hannover, Germany, pp 33-37

Cháb J, Šrámek J, Pokorný L, Chlupáčová M, Manová M, Vejnar Z, Waldhausrová J, ŽÁček V (1997) The Teplá Barrandian Unit. In: VRÁNA S, ŠTĚDRÁ V (eds) Geological Model of Western Bohemia Related to the KTB Borehole in Germany. Sbor Geol Věd, Geol 47: 80-104

СнÁ́B J, StRÁNík Z, EliÁš M (2007) Geological map of the Czech Republic 1:500 000. Czech Geol Survey, Prague (in Czech)

Dallmeyer RD, Urban M (1998) Variscan vs Cadomian tectonothermal activity in northwestern sectors of the Teplá-Barrandian Zone, Czech Republic: constraints from $\mathrm{Ar} / \mathrm{Ar}$ ages. Geol Rundsch 87: 94-106

Dörr W, Fiala J, Vejnar Z, Zulauf G (1998) U-Pb zircon ages and structural development of metagranitoids of the Teplá Crystalline Complex: evidence for pervasive Cambrian plutonism within the Bohemian Massif(Czech Republic). Geol Rundsch 9: 135-149

Dörr W, Zulauf G, Fiala J, Franke W, Vejnar Z (2002) Neoproterozoic to Early Cambrian history of an active plate margin in the Teplá-Barrandian Unit - a correlation of U-Pb isotopic-dilution-TIMS ages (Bohemia, Czech Republic). Tectonophysics 352: 65-85
Edel JB, Schumann K, Holub FV (2003) Anticlockwise and clockwise rotations of the eastern Variscides accommodated by dextral lithospheric wrenching: palaeomagnetic and structural evidence. J Geol Soc, London 160: 209-218

FARYAD SW (2012) High-pressure polymetamorphic garnet growth in eclogites from the Mariánské Lázně Complex (Bohemian Massif). Eur J Mineral 24: 483-497

FLoyd PA WinCHESTER JA (1975) Magma type and tectonic setting discrimination using immobile elements. Earth Planetary Sci Lett 27: 211-218

Franke W (2000) The mid-European segment of the Variscides: tectonostratigraphic units, terrane boundaries and plate tectonic evolution. In: Franke W, AltherR R, HAAK V, OnCKen O (eds) Orogenic Processes: Quantification and Modelling in the Variscan Belt of Central Europe. Geological Society, London, Special Publications 179: 35-61

Gallien F, Mogessie A, Hauzenberger CA, Buerg E, Delpino S, Castro De Machuca B (2012) On the origin of multi-layer coronas between olivine and plagioclase at the gabbro-granulite transition, Valle Fértil-La Huerta Ranges, San Juan Province, Argentina. J Metamorph Geol 30: 281-301

GolDSMITH JR (1982) Review of the behaviour of plagioclase under the metamorphic conditions. Amer Miner 67: 643-652

Grove LT, Ferry MJ, Spear FS (1983) Phase transitions and decomposition relations in calcic plagioclase. Amer Miner 68: 41-59

Haas GJlm De, NiJland TG, Valbracht PJ, Maijer C, Verschure R, Andersen T (2002) Magmatic vs metamorphic origin of olivine-plagioclase coronas. Contrib Mineral Petrol 143: 537-550

Holland TJB AX software. Accessed on August 24, 2016, at http://www.esc.cam.ac.uk/research/research-groups/ research-projects/tim-hollands-software-pages/ax

Holland TJB, Powell R (1998) An internally consistent thermodynamic data set for phases of petrological interest. J Metamorph Geol 145: 309-343

Hrouda F, Fayad SW, Chlupáčová M, JeŘÁbek P (2014) Magnetic fabric in amphibolized eclogites and serpentinized ultramafites in the Mariánské Lázně Complex (Bohemian Massif, Czech Republic): product of exhumation-driven retrogression? Tectonophysics 629 : 260-274

JANOUŠEK V, FARROW CM, ERBAN V (2006) Interpretation of whole-rock geochemical data in igneous geochemistry: introducing Geochemical Data Toolkit (GCDkit). J Petrol 47:1255-1259

JeLínek E, ŠTĚDRÁ V, ChÁB J (1997) The Mariánské Lázně Complex. In: VRÁna S, ŠTĚDRÁ V (eds) Geological Model of Western Bohemia Related to the KTB Borehole in Germany. Sbor Geol Věd, Geol 47: 61-70 
Jensen LS (1976) A New Cation Plot for Classifying Subalkalic Volcanic Rocks. Ontario Geological Survey Miscellaneous Papers 66, pp 1-22

JoESTEN R (1986) The role of magmatic reactions, diffusion and annealing in the evolution of coronitic microstructures in troctolitic metagabbro from Risor, Norway. Mineral Mag 50: 441-469, 474-479

Kachlík V (1993) The evidence for late Variscan nappe thrusting of the Mariánské Lázně Complex over the Saxothuringian Terrane (west Bohemia). J Czech Geol Soc 38: $43-58$

KACHLíK V (1997) Contact metamorphic rocks from the mantle of the Lestkov Pluton and their significance for reconstruction of the tectonometamorphic development of the Teplá-Barrandian Unit. Zpr geol výzk r. 1996, 81-82 (in Czech)

Kastl E, Tonika J (1984) The Mariánské Lázně metaophiolitic complex (West Bohemia). Krystalinikum 17: 59-76

Kohn MJ, Spear FS (1990) Two new geobarometers for garnet amphibolites, with applications for southeastern Vermont. Amer Miner 75: 89-96

KRETZ R (1983) Symbols of rock-forming minerals. Amer Miner 68: 277-279

Kreuzer H, Seidel E, Schüssler U, Okrusch M, Lenz KL, RASCHKA H (1989) K-Ar geochronology of different tectonic units at the northwestern margin of the Bohemian Massif. Tectonophysics 157: 149-178

LARIKOVA TL (2000) Genesis of drusitic (corona) textures around olivine and orthopyroxene during metamorphism of gabbroids in Northern Belomorie, Karelia. Petrology 8: 384-401

LARIKOVA TL, ZARAISKI GP (2009) Experimental modelling of corona textures. J Metamorph Geol 27: 139-151

Leake BE, Woolley AR, Arps CES, Birch WD, Gilbert MC, Grice JD, Hawthorne FC, Kato A, Kisch HJ, Krivovichev VG, Linthout K, Laird J, Mandarino JA, Maresch WV, Nickel EH, Rock NMS, Schumacher JC, Smith DC, Stephenson NCN, Ungaretti L, Whittaker EJW, YouzHi G (1997) Nomenclature of amphiboles: report of the Subcommittee on Amphiboles of the International Mineralogical Association, Commission on New Minerals and Mineral Names. Canad Mineral 35: 219-246

Matte P, Maluski H, Rajlich P, Franke W (1990) Terrane boundaries in the Bohemian Massif: results of large scale Variscan shearing. Tectonophysics 177: 151-170

Morimoто CN (1988) Nomenclature of pyroxenes. Mineral Mag 52: 535-550

Morriset CE, Scontes JS (2008) Origin of zircon rims around ilmenite in mafic plutonic rocks of Proterozoic anorthosite suites. Canad Mineral 46: 289-304

O’Brien PJ, Duyster J, Grauert B, Schreyer W, Stockhert B, Weber K (1997) Crustal evolution of the KTB site: from oldest relics to the late Hercynian granites. J Geophys Res 102 (B8): 18203-18220

PeARCE JA (1996) A user's guide to basalt discrimination diagrams. In: WyMAN DA (ed) Trace Element Geochemistry of Volcanic Rocks: Applications for Massive Sulphide Exploration. Geological Association of Canada, Short Course Notes 12, pp 79-113

Pearce JA (2008) Geochemical fingerprinting of oceanic basalts with applications to ophiolite classification and the search for Archean oceanic crust. Lithos 100: 14-48

PEARCE JA (2014) Immobile element fingerprinting of ophiolites. Elements 10: 101-108

PEŘEstý V (2012) Polyphase Structural Evolution of Superstructure and Infrastructure in Orogenic Zones. Unpublished MSci. thesis, Charles University in Prague, pp 1-146 (in Czech)

Pitra P, Kouamelan AN, Ballèvre M, Peucat JJ (2010) Palaeoproterozoic high-pressure granulite overprint of the Archean continental crust: evidence for homogeneous crustal thickening (Man Rise, Ivory Coast). J Metamorph Geol 28: 41-58

PoldervaArt A, Gilkey AK (1954) On clouded plagioclase. Amer Miner 39: 75-91

Powell R, Holland TJB (1985) An internally consistent dataset with uncertainties and correlations: 1. Methods and a worked example. J Metamorph Geol 3: 327-342

Powell R, Holland TJB (1988) An internally consistent dataset with uncertainties and correlations: 3. Applications to geobarometry, worked examples and a computer program. J Metamorph Geol 6: 173-204

Powell R, Holland TJB (1994) Optimal geothermometry and geobarometry. Amer Miner 79:120-133

Powell R, Holland TJB (2008) On thermobarometry. J Metamorph Geol 26: 155-179

Powell R, Holland TJB, Worley B (1998) Calculating phase diagrams involving solid solutions via non-linear equations with examples using THERMOCALC. J Metamorph Geol 16: 577-588

Ravna EK (2000) Distribution of $\mathrm{Fe}^{2+}$ and $\mathrm{Mg}$ between coexisting garnet and hornblende in synthetic and natural systems: an empirical calibration for garnet-hornblende Fe-Mg geothermometer. Lithos 53: 267-277

Schulmann K, KonopáseK J, JanouŠEK V, LeXa O, LardeauX J-M, Edel J-B, ŠtípskÁ P, Ulrich S (2009) An Andean type Palaeozoic convergence in the Bohemian Massif. CR Geosci 341: 266-286

Schulmann K, LeXa O, Janoušek V, Lardeaux J-M, Edel J-B (2014) Anatomy of a diffuse cryptic suture zone: an example from the Bohemian Massif, European Variscides. Geology 42: 275-278

Sláma J, Košler J, Pedersen RB (2007) Behaviour of zircon in high-grade metamorphic rocks: evidence from Hf isotopes, trace elements and textural studies. Contrib Mineral Petrol 154: 335-356 
SPEAR FS (1977) Evidence for miscibility gap in plagioclase feldspar in composition range $\mathrm{An}_{39}-\mathrm{An}_{88}$. Carnegie I Wash Yearbook 76: 619-621

SPEAR FS, MARCuSSEN J (1997) Mineral zoning, P-T-X-M phase relations, and metamorphic evolution of some Adirondack Granulites, NY. J Petrol 38: 757-783

St-Onge MR, IJEwliw OJ (1996) Mineral corona formation during high-P retrogression of granulitic rocks, Ungava Orogen, Canada. J Petrol 37: 553-582

ŠTĚDRÁ V (2001) Tectonometamorphic Evolution of the Mariánské Lázně Complex, Western Bohemia, Based on the Study of Metabasic Rocks. Unpublished Ph.D. thesis, Charles University, Prague, pp 1-136

ŠTĚdRÁ V, KRYZA R, KAChLíK V (2002) Coronitic metagabbros of the Mariánské Lázně Complex and Teplá Crystalline Unit: inferences for the tectonometamorphic evolution of the western margin of the Teplá-Barrandian Unit, Bohemian Massif. In: Winchester JA, Pharaoh TC, Verniers J (eds) Palaeozoic Amalgamation of Central Europe. Geological Society, London, Special Publications 201, pp 217-236

Sun SS, McDonough WF (1989) Chemical and isotopic systematics of oceanic basalts: implications for mantle composition and processes. In: SAunders AD, Norry M (eds) Magmatism in the Ocean Basins. Geological Society, London, Special Publications 42, pp 313-345

Timmermann H, Štědrá V, Gerdes A, Noble S, Parrish RR, DÖRR W (2004) The problem of dating HP meta- morphism: an U-Pb isotope and geochemical study on eclogites and related rock of the Mariánské Lázně Complex, Czech Republic. J Petrol 45: 1311-1338

Timmermann H, Dörr W, Krenn E, Finger F, Zulauf G (2006) Conventional and in situ geochronology of the Teplá Crystalline Unit, Bohemian Massif: implications for the processes involving monazite formation. Int J Earth Sci 95: 629-648

Whitney PR, McLelland JM (1973) Origin of coronas in metagabbros of the Adirondack Mts., N. Y. Contrib Mineral Petrol 39: 81-98

Zulauf G (1997) Von der Anchizone bis zur Eklogitfazies: Angekippte Krustenprofile als Folge der cadomischen und variscischen Orogenese im Teplá-Barrandium (Böhmische Masse). Geotekt Forsch 89: 1-302

Zulauf G (2001) Structural style, deformation mechanisms and paleostress along an exposed crustal section: constraints on the rheology of quartzofeldspathic rocks at supra- and infrastructural levels (Teplá-Barrandian Unit, Bohemian Massif). Tectonophysics 332: 211-237

ŽÁČEK V (1994) Garnets and metamorphic evolution of the Teplá Crystalline Complex, western Bohemia. Zbl Geol Paläontol, Teil I: 847-856

ŽÁK J, KRAft P, HajnÁ J (2013) Timing, styles, and kinematics of Cambro-Ordovician extension in the TepláBarrandian Unit, Bohemian Massif, and its bearing on the opening of the Rheic Ocean. Int J Earth Sci 102: 415-433 